\title{
Kütahya ve Köprüören Ovalarındaki Yüzey ve Yeraltısularının Hidrojeokimyasal Özellikleri ve İz Element İçerikleri
}

\author{
Meral ÖZCAN1 10 , Hüseyin KARAKUŞ ${ }^{*}$ (i) \\ 1,2Dumlupınar Üniversitesi, Mühendislik Fakültesi, Jeoloji Müh. Bölümü, 43100, Kütahya, Türkiye
}

(Alınış / Received: 19.04.2019, Kabul / Accepted: 30.05.2019, Online Yayınlanma / Published Online: 30.08.2019)

Anahtar Kelimeler

Yeraltısuyu,

Jeokimya,

İz element,

Kütahya,

Köprüören
Özet: Bu çalışma Kütahya ve Köprüören ovalarındaki yüzey ve yeraltısularının hidrojeokimyasal özelliklerinin incelenmesi ve iz element içeriklerinin belirlenmesi amacıyla yapılmıştır. Her iki ovada bulunan yüzey ve yeraltısularının majör iyon ve iz element analizleri yapılmıştır. Major iyon analizlerine göre bölgedeki doğal suların kimyasal fasiyesi karbonatlı kayalarca denetlenmektedir. Örneklenen sularda bazı iz element derişimlerinin içme suyu standartlarındaki sınır değerleri aștı̆ı̆ belirlenmiștir. Her iki ovada özellikle arsenik (As) derişimleri on farklı noktada içme suları için 10 ppb olarak önerilen sınır değeri aşmaktadır. Köprüören ovasında Enne Barajı'na drene olan Köprüören Deresi'nde kurşun $(\mathrm{Pb})$ ve antimon $(\mathrm{Sb})$ derişimleri eșik değerlerin üzerindedir. Arsenik ve antimon dıșında demir $(\mathrm{Fe})$, çinko $(\mathrm{Zn})$ ve mangan $(\mathrm{Mn})$ derișimlerinin yerel sanayi kuruluşlarının bulunduğu kesimlerde veya maden işletmeleri civarında yüksek derişimlere ulaştığı belirlenmiştir.

\section{Hyrogeochemical Features and Trace Element Contents of Surface and Groundwaters in Kütahya and Köprüören Plains}

\section{Keywords}

Groundwater,

Geochemistry,

Trace element,

Kütahya,

Köprüören

\begin{abstract}
The aim of this study is to investigate the geochemical properties of surface and groundwater in Kütahya and Köprüören plains and to determine the trace element contents. Major ion and trace element analysis of surface and groundwater in both plain were performed. According to major ion analysis, the chemical facies of natural waters in the region are controlled by carbonate rocks. It is determined that some trace element concentrations exceed the limit values in drinking water standards. Particularly, arsenic (As) concentrations in both plains exceed the recommended limit value of $10 \mathrm{ppb}$ for drinking water at ten different points. The concentration of lead $(\mathrm{Pb})$ and antimony $(\mathrm{Sb})$ at Köprüören creek, which is drained to Enne Dam in Köprüören plain, is above the threshold values. In addition to arsenic and antimony, the concentrations of iron (Fe), zinc ( $\mathrm{Zn})$ and manganese $(\mathrm{Mn})$ were found to be high in the regions where the local industrial establishments were located or in the vicinity of the mine enterprises.
\end{abstract}

\section{Giriş}

Günümüzde modern yaşamın gereği olarak endüstrileşme, şehirleşme ve artan nüfusa paralel olarak çevre kirliliği artmakta, özellikle yağıșlı dönemlerde antropojenik kaynaklı kirletici unsurlar toprağa ve doğal sulara karışmaktadır. Bu kirletici unsurların başında ağır metaller/iz elementler yer alır. Bu elementlerin bazıları kurşun (Pb), kadmiyum (Cd), çinko (Zn), antimon (Sb), nikel (Ni), krom (Cr), arsenik (As), clva (Hg) ve selenyum (Se) dir. Bu elementler için ulusal (TS266) ve uluslararası [1] içme suyu standartlarında verilen sınır değerler 5-50 $\mu \mathrm{g} / \mathrm{L}$ arasında değişmektedir.

Kütahya ilinde kirliliğe neden olabilecek faktörler çeşitli sanayi kuruluşlarının yakıt tüketiminden kaynaklanan gazlar ve fosseptik atıklar, tarımsal faaliyetlerde kullanılan suni ilaç ve gübreler, yerleşim yerlerinin kanalizasyon atıkları, eski gömülü çöp yığınları, ısınma amaçlı kullanılan soba ve doğalgaz bacalarından çıkan $\mathrm{CO}, \mathrm{CO}_{2}$ ve $\mathrm{SO}_{2}$ gazları gibi hem havayı hem de doğal suları kirletebilecek unsurlardır. Yörede bulunan gümüș, termik santral, azot sanayi ve yersel önemli sanayi kuruluşları gibi fabrika baca gazı 
ve fosseptik atıklarının da kirletici özellikleri göz ardı edilemeyecek kadar önemlidir. Bu konuda yapılan çalışmalarda [2, 3] Köprüören Havzası'nın güneyinde gümüş içeren metalik maden yatakların işletilmesi, kuzeyinde de linyit yatakları ile ilişkili arsenikçe zengin minerallerin çözünmesi sonucunda bölgedeki yüzey ve yeraltısularında As kirliliğinin varlığı saptanmıştır. Benzer bir çalışmada [4] Köprüören Ovasında gümüş madenciliğinin yapıldığı sahaya yakın alanlardaki yeraltısularında As ile birlikte Sb derişimlerinin içme suyu standartlarındaki eşik değerlerin aşıldığı belirlenmiştir.

Günümüzde Kütahya ve Köprüören ovalarında yeraltısuyu kullanımı tarımsal sulama ile sinırlıdır. İçme-kullanma suyu ihtiyacı Kütahya il merkezine yaklaşık $18 \mathrm{~km}$ mesafede bulunan Gelinkaya ve Porsuk kaynak suyu sistemi ile karşılanmaktadır [5]. Ancak, artan nüfus ve sanayileşmeye paralel olarak kullanılabilir nitelikteki su ihtiyacının artması kaçınılmazdır. Bununla birlikte Meteoroloji Genel Müdürlüğü tarafından hazırlanan RCP4.5 iklim değişim senaryosuna göre birinci dönemde (20162040) özellikle ilkbahar yağışlarında yurdun büyük bir bölümünde \%20'lere varan düşüşler meydana geleceği öngörülmektedir [6]. Aynı senaryoya göre 2041-2070 yılları arasını kapsayan ikinci dönemde ise Kütahya ilini içini alan bölgede mevsimlere bağlı olarak yağışlarda \%5-\%20 arasında düşüşler beklenmektedir.

Yukarıda verilen bilgiler ışığında Kütahya ve Köprüören ovalarındaki yeraltısularının yakın gelecekte olmasa bile orta vadede bölgedeki yerleşimlerin içme ve kullanma suyu ihtiyacını karşılanması amacıyla kullanılması olasılığı artmaktadır. Bu bağlamda Kütahya ve Köprüören ovalarındaki yüzey ve yeraltısularının mevcut niteliğinin tarımsal sulama ve içme suyu olarak kullanılabilirliğinin belirlenmesi ivedilik arz etmektedir.

Sunulan bu çalışmada, Kütahya ve Köprüören ovalarındaki yüzey ve yeraltısularının hidrojeokimyasal özellikleri incelenmiş, iz element içerikleri ve olası iz element kirlilik durumları araştırılmıştır. Çalışmada kullanılan veriler benzer amaç ve kapsamda hazırlanmış olan yüksek lisans tezinden [7] derlenmiştir.

\section{Materyal ve Metot}

\subsection{Arazi çalışmaları}

Öncelikle arazi çalışmaları ile her iki ovada bulunan su noktaları (çoğunlukla sığ keson kuyular ve dereler) tespit edilmiştir. GPS yardımıyla koordinatları alınmış örneklemeye uygun noktalar Coğrafi Bilgi Sistemi (CBS) tabanlı ArcGIS yazılımına aktarılarak her iki ovayı temsil edecek konumsal dağılıma sahip noktalar seçilmiştir. Ölçüm ve örnekleme çalışmaları bölgenin yağışlı dönemi olarak kabul edilen Nisan 2017 ayında yapılmış olup, genelde Kuvaterner ve Pliyo-Kuvaterner çökellerde açılmış kuyular ve derelerden olmak üzere toplamda 43 adet su örneği alınmıştır.

Örnekleme sırasında kuyularda seviye ölçümleri Heron Instruments Conductivity Plus model seviye ölçer ile yapılmıştır. Örneklere ait sıcaklık, pH, elektriksel iletkenlik (EC) ölçümleri için YSI 556 MPS model multiparametre cihazı kullanılmıştır. Ölçümler öncesinde cihazlar standart çözeltilerle $(\mathrm{pH}$ için $\mathrm{pH}=$ 4.01 ve $\mathrm{pH}=7.01$; EC için $\mathrm{EC}=1413 \mu \mathrm{S} / \mathrm{cm}$ ) kalibre edilmiştir.

Alkalinite tayini arazi koşullarında titrasyon ile yapılmıştır. 250 ml'lik polietilen şişeler ile alınan örnekler analizlerin yapılacağı laboratuvara ulaştırılıncaya kadar $+4{ }^{\circ} \mathrm{C}$ 'de koruma altına alınmıştır.

\subsection{Kimyasal analizler}

Major iyon ve iz element analizleri Hacettepe Üniversitesi, Jeoloji Müh. Bölümü $\mathrm{Su}$ Kimyası laboratuvarında yapılmıştır.

- $\mathrm{Ca}^{+2}, \mathrm{Mg}^{+2}, \mathrm{Na}^{+}, \mathrm{K}^{+}, \mathrm{Cl}^{-}, \mathrm{SO}_{4}^{-2}$, vb. major iyon ile $\mathrm{F}^{-}$, $\mathrm{Br}^{-}, \quad \mathrm{PO}_{4}^{-3}, \quad \mathrm{NO}_{3}^{-}$ve $\mathrm{NO}_{2}^{-}$analizleri iyon kromotografi yöntemi (Dionex model) ile,

- $\mathrm{CO}_{3}-\mathrm{HCO}_{3}$ analizleri ise hata sinırı $\pm 3 \mathrm{mg} / \mathrm{l}$ olan titrimetrik yöntem ile,

- İz element analizleri ICP-MS yöntemi ile gerçekleştirilmiştir.

İyon dengesine dayalı elektronötralite hesaplamasına göre analiz hataları \% $0.04 \quad$ - $\% 4.5$ arasında değişmekte olup, jeokimyasal değerlendirmeler için analiz sonuçları güvenilir olarak kabul edilmiştir.

\subsection{Sonuçların değerlendirilmesi}

Arazi ölçüm verileri haritalara aktarılmış, elde edilen fiziksel ve kimyasal veriler ArcGIS yazılımının "Topo to Raster" eklentisi yardımı ile 50 m x 50 m çözünürlükte raster formatına dönüştürülerek alansal dağılım haritaları yapılmıștır. Kimyasal analiz sonuçlarından litoloji ve hidrojeolojik yapı arasındaki ilişkinin açıklanması için hidrojeokimyasal çalışmalarda yaygın olarak yararlanılan Piper diyagramı kullanılmıştır. Örneklenen suların tarımsal sulamaya uygunlukları Wilcox ve ABD tuzluluk Lab. diyagramları ile değerlendirilmiştir. İz element analiz sonuçları TS266-İnsani Tüketim Amaçlı Sular Yönetmeliği ve Dünya Sağlık Organizasyonu (WHO) "İçme Suyu Kalitesi için Kılavuz Değerleri" çerçevesinde değerlendirilerek elde edilen bulgular öneriler eşliğinde sunulmuştur. 


\section{Bulgular}

\section{1. İnceleme alanının tanıtılması}

Kütahya ve Köprüören ovaları Ege Bölgesinin İç Batı Anadolu bölümünde, Kütahya merkez ilçe ili sınırları içinde bulunur (Şekil 1). Kuzeybatı-güneydoğu uzanımlı bu ovalar güneyde Yellice dağı, kuzeyde ise Karaöz dağlarıyla sınırlandırılmıştır.

İnceleme alanında ana akarsu ağını Porsuk Çayı ve onun yan kolu olan Felent Çayı oluşturur. Her iki akarsu, Kütahya ovasının kuzey sınırında birleșerek Ilıca civarında Porsuk baraj gölüne dökülür. Kütahya ve Köprüören ovaları birbirinden Felent Çayı üzerinde inşa edilmiş Enne Barajı'nın bulunduğu dar bir boğazdan ayrılır (Şekil 1).
Köprüören Ovası 1020 m -1050 m kotları arasında yer alırken, Kütahya Ovası 920 m -970 m kotları arasında yer almaktadır. Her iki ovada da arazi eğimi \%1'in altındadır. Düşük eğimli ovalık alanlarda tarımı yapılan başlıca ürünler buğday, arpa, nohut ve şeker pancaridir.

Çalışma alanı iklim olarak Türkiye'nin batısında görülen Akdeniz iklimi ile İç Anadolu'nun tipik karasal iklimi arasında geçiş bölgesi olarak dikkat çeker. Yazlar sıcak ve kurak, kışlar soğuk ve yağıșlı geçer. Yıllık ortalama sıcaklık ve yıllık ortalama yağış yüksekliği sırası ile $10.8{ }^{\circ} \mathrm{C}$ ve $556.8 \mathrm{~mm}$ dir.

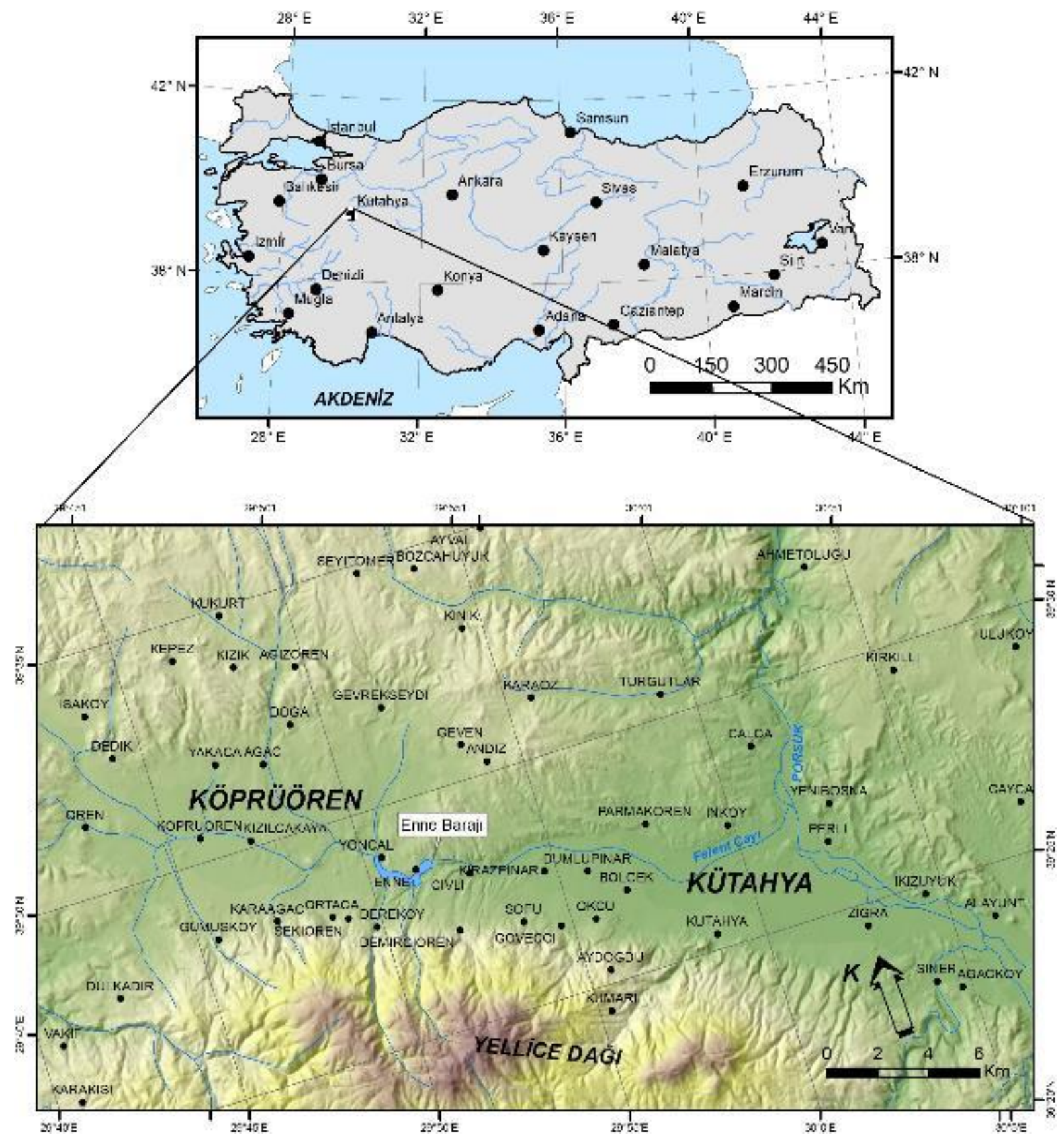

Şekil 1. Kütahya ve Köprüören ovaları yer bulduru haritası 


\subsection{Jeolojik ve hidrojeolojik özellikler}

Kütahya ve Köprüören ovaları, Türkiye'nin neotektonik dönemi gerilmeli tektonik rejimi etkisinde gelişmiş çöküntü yapılarındandır. Ovaların gelişimi güneylerinde yer alan yükselim alanları ile düzlükleri ayıran eğim bileşeni baskın KB-GD gidişli basamaklı bir fay dizisi tarafından denetlenmektedir. Ovaları çevreleyen yükselim alanlarında Paleozoyik ve Mesozoyik dönemlerine ait birimler yer alır. Ovalık bölüm ise Kuvaterner ve Pliyo-Kuvaterner genç çökel dolguludur. Çalıșma alanı ve çevresinin jeoloji haritası MTA tarafından hazırlanmış olan 1/500000 ölçekli İzmir ve Ankara paftalarından [8, 9] derlenerek Şekil 2'de sunulmuştur.

İnceleme alanında temel kayacı Yellice Dağı ve eteklerinde yüzeylenen, baskın litolojisi mikaşist olan ve yer yer mermer mostraları içeren Sarıcasu Formasyonu oluşturur. Bu birimin üzerinde kristalize kireçtaşı ve mermerlerden oluşan Arıkaya formasyonu yer alır. Fay zonuna yakın yerlerde yoğun makaslamaya uğramış birimin kalınlığı $400 \mathrm{~m}$ civarında olup, Kütahya Fay Zonuna yakın yerlerde fay pudrası ismiyle nitelendirilmiştir [10].

Çalışma alanı içindeki Tavşanlı Zonu kayaçları farklı araştırmacılar tarafından Ovacık Melanjı Ofiyoliti adı altında incelenmiștir. Ovacık Melanjı yüksek basınç/düşük sıcaklık metamorfizması geçirmiş bazik lav, volkanik aglomera, tüf, radyolaryalı çört, şeyl, serpantinit, talk, grovak ve kireçtaşı bloklarından oluşmaktadır [11].
Bölgedeki karasal çökeller kaba konglomera, kumtaşı ve üste doğru kiltaşı marnlardan oluşan Alt-Orta Miyosen yaș aralığına sahip Beke Formasyonu [12] ile başlar. Daha üstte ise Kütahya Ovası'nın KD'sunda geniş bir alanda yüzeylenen Orta Miyosen yaşlı genelde kirli beyaz, açı sarı renkli Çayca Tüf birimi [10] gelir.

Kireçtaşı ve marndan oluşan gölsel karbonatlar 150 m’yi bulan kalınlığıyla bölgede geniş alanda yüzeylenir [10]. Kütahya genelinde yapılan bölgesel jeolojik çalışmalarda bu birimler Üst Miyosen yaşlı Emet Formasyonu adıyla ayırtlanmıştır [13].

Kütahya ovasının kuzey-kuzeybatısında ve Yellice Dağı eteklerinde uzun bir hat boyu gözlemlenen Pliyo-Kuvaterner birimler Kirazpınar Formasyonu olarak adlandırılmış [10] olup pekişmiş-yarı pekişmiş, sarımsı, bej ve kırmızımsı renkli çakıltaşı, kumtaşı, silttaşı ve çamurtaşından oluşur. Yellice Dağı etekleri boyunca Kütahya Fay zonunun değișik kesimlerinde oluşan alüvyal yelpazeler ise Kütahya Formasyonu olarak ayırtlanmıştır [10].

Köprüören Ovası'nda çakıl, kum, silt ve kilden oluşan tutturulmamış çökeller "eski alüvyon" adı altında incelenmiştir $[10,12]$. Kütahya Ovası'ndaki alüvyon ise her iki ovada drenajı sağlayan Felent Çayı ve Porsuk Çayının bıraktı̆̆ çökellerdir. Genellikle çakıl, kum, silt, kil boyutu malzemelerden oluşan kalınlığı bazı sondaj kuyularında 100 m'yi aştığı gözlenmiştir [14].

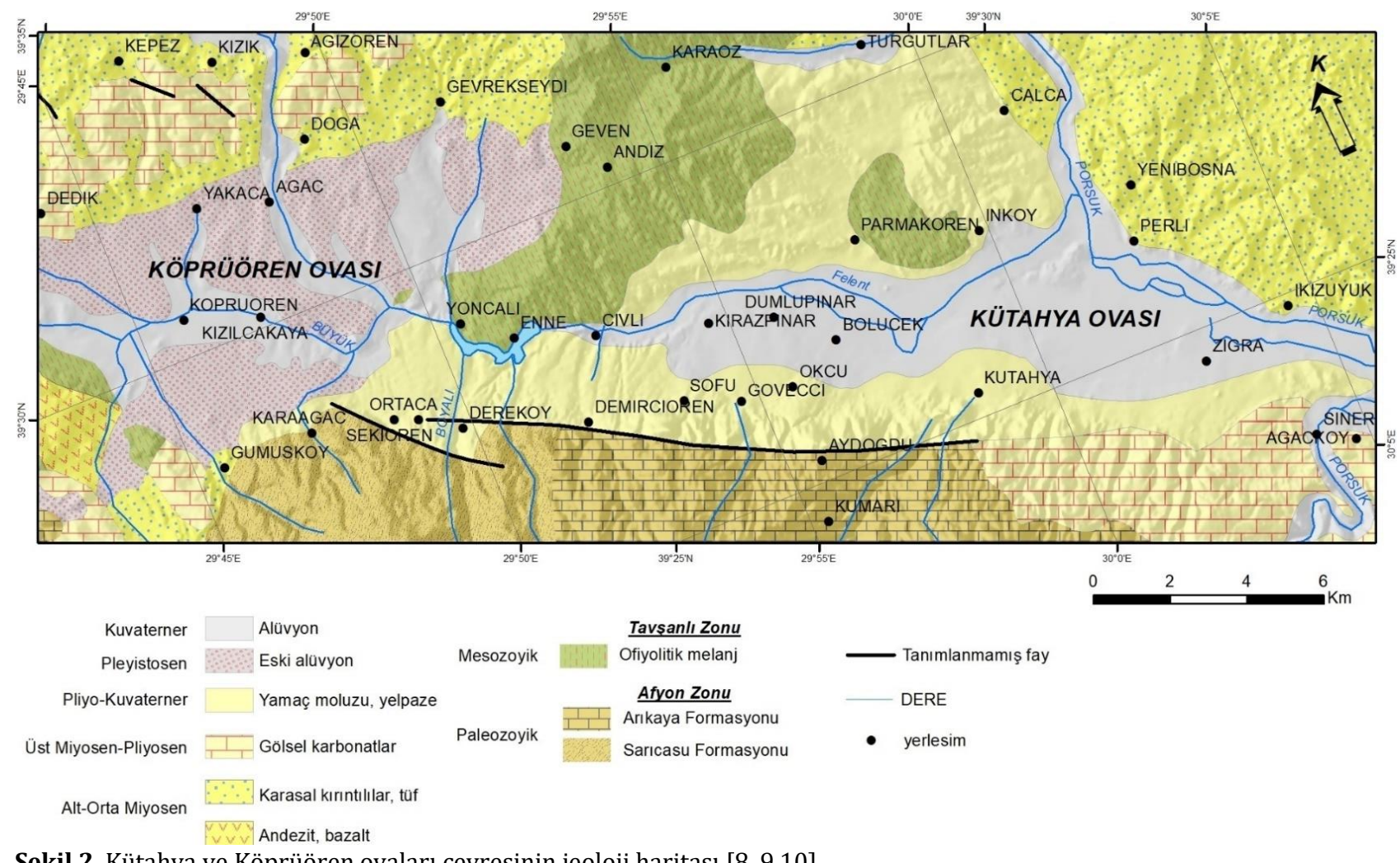

Şekil 2. Kütahya ve Köprüören ovaları çevresinin jeoloji haritası $[8,9,10]$ 
Kütahya ve Köprüören ovalarındaki akifer sistemini alüvyon birimler oluşturur. Kütahya Ovası'ndaki serbest akifer özelliğindeki alüvyon birimlerin kapladıkları alan yaklaşık $80 \mathrm{~km}^{2}$ dir. Alüvyon kalınlığı ise çoğunlukla 10-100 m arasında değişmektedir. Alüvyon kalınlığı ova kenarlarında 1020 m iken ova merkez bölümünde yer alan Kütahya il merkezi ile azot sanayi arasında kalan bölgede ise yer yer 100 m'ye ulaşır. Ovada açllan sondaj kuyularından yapılan pompaj deneyleri ile 3-40 l/s arası değişen debiye ulaşıldığı, özgül debilerin 1-3 $\mathrm{l} / \mathrm{s} / \mathrm{m}$ arası değiștiği, iletimlilik katsayısının ise ortalama $210 \mathrm{~m}^{3} /$ gün$/ \mathrm{m}$ olduğu tespit edilmiştir. [15]. Yeraltısuyu tablası oldukça sı̆̆ derinlikte, yüzeyden 1.5-9 m arasında değişmektedir (Şekil 3). Felent Çayı'nın akış yaptığı Bölcek mah. kuzeyi ile Parmakören köyü güneyi arasında kalan bölümde yer yer bataklık oluşumları mevcuttur.

Köprüören Ovası'nda alüvyon yaklaşık $88 \mathrm{~km}^{2 \prime}$ lik alanı kapsamaktadır. Kalınlığı ise $40 \mathrm{~m}$ civarındadır [14].

İnceleme alanında yeraltısuyu seviye tespiti amacıyla ovalarda yer alan sı ğ keson kuyular ile birlikte Paleozoyik şist ve mermerlerde açılmış olan kuyularda da seviye ölçümü yapılmıştır. Kuyular ile birlikte yükselim alanlarında yer alan kaynaklar ve ovadaki yüzey suları doğal yeraltısuyu kotu kabul edilerek yeraltısuyu eş-seviye haritası oluşturulmuştur (Şekil 3).

Yeraltısuyu akım yönleri yüzey sularının akımı yönü ile uyumlu olup Köprüören Ovası'nda batıdan doğuya doğrudur. Kütahya Ovası'nda güneyde topoğrafyanın yükselmesiyle yeraltısuyu seviyesi de yükselmekte ve ovaya doğru topoğrafyaya uygun olarak azalmaktadır. Bu ovadaki akım yönünü Felent ve Porsuk Çayları ile uyumlu olup güney, doğu ve batıdan gelen akımlar Porsuk Çayı akış yönünü izleyerek kuzeye doğru yönelmektedir.

\subsection{Hidrojeokimya}

Çalışma kapsamında örneklenen su noktaların koordinat bilgileri ve fiziksel özellikleri Tablo 1'de, majör iyon analiz sonuçları Tablo 2'de sunulmuştur. İnceleme alanında ölçülen suların sıcaklıkları ise 7.2 ${ }^{\circ} \mathrm{C}$ ile $16{ }^{\circ} \mathrm{C}$ arasında değișmektedir (Tablo 1). Sicaklığın nispeten yüksek olduğu noktalar şehirleşmenin olduğu alanlarda gözlenmektedir. Bu olgu "kentsel ısı adası" etkisi olarak tanımlanmakta, kentleşmeden dolayı yerel ısınmadan kaynaklanan iklimsel olmayan bozulmaların bir sonucu olarak açıklanmaktadır [16]. Yüzey sularında ve kırsal kesimlerde bulunan yeraltısularında ise sıcaklıklar göreceli olarak daha düşüktür.

EC değerleri 320 - $1860 \mu \mathrm{S} / \mathrm{cm}$ arasındadır (Tablo 1). Ölçüm sonuçlarına göre EC eş dağılım haritası oluşturularak Şekil 4' te sunulmuştur. Buna göre; her iki ovanın orta kesimlerinde ovaları sınırlayan yükseltilerden ovalara doğru gerçekleşen yeraltısuyu akım yönü boyunca su-kayaç etkileșimi sonucu iletkenlik artışı gözlenmektedir. PH değerleri ise 7.0 ile 8.5 arasında, nötre yakın hafif alkali suları ifade etmektedir.

Kütahya ve Köprüören ovalarındaki yüzey ve yeraltısuyu kimyasını denetleyen süreçler, bu amaç için yaygın olarak kullanılan Piper diyagramı ile incelenmiștir. İnceleme alanındaki su noktalarının Şekil 5'te yer alan Piper diyagramı üzerindeki konumlarına göre, sular kimyasal fasiyes olarak çoğunlukla $\mathrm{Ca}-\mathrm{HCO}_{3}$ ile $\mathrm{Mg}-\mathrm{HCO}_{3}$ tipi sular sınıfına girmektedirler. Kimyasal fasiyes türlerine göre sularda $\mathrm{Ca}, \mathrm{Mg}$ ve $\mathrm{HCO}_{3}$ iyonlarının baskın olmasını, jeolojik yapı dikkate alındığında, bölge genelinde geniș yayılım gösteren Arıkaya Formasyonu ile Gölsel karbonatları ile ilișkilendirmek mümkündür. Karbonatlı kayaç (kireçtaşı ve dolomit) mineralleri kalsit ve dolomitin çözünme tepkimeleri sonucunda, su fazına sırası ile $\mathrm{Ca}, \mathrm{Mg}, \mathrm{HCO}_{3}$ geçer:

$$
\mathrm{CaCO}_{3}+\mathrm{H}_{2} \mathrm{O}+\mathrm{CO}_{2} \leftrightarrow \mathrm{Ca}^{+2}+2 \mathrm{HCO}_{3}^{-}
$$

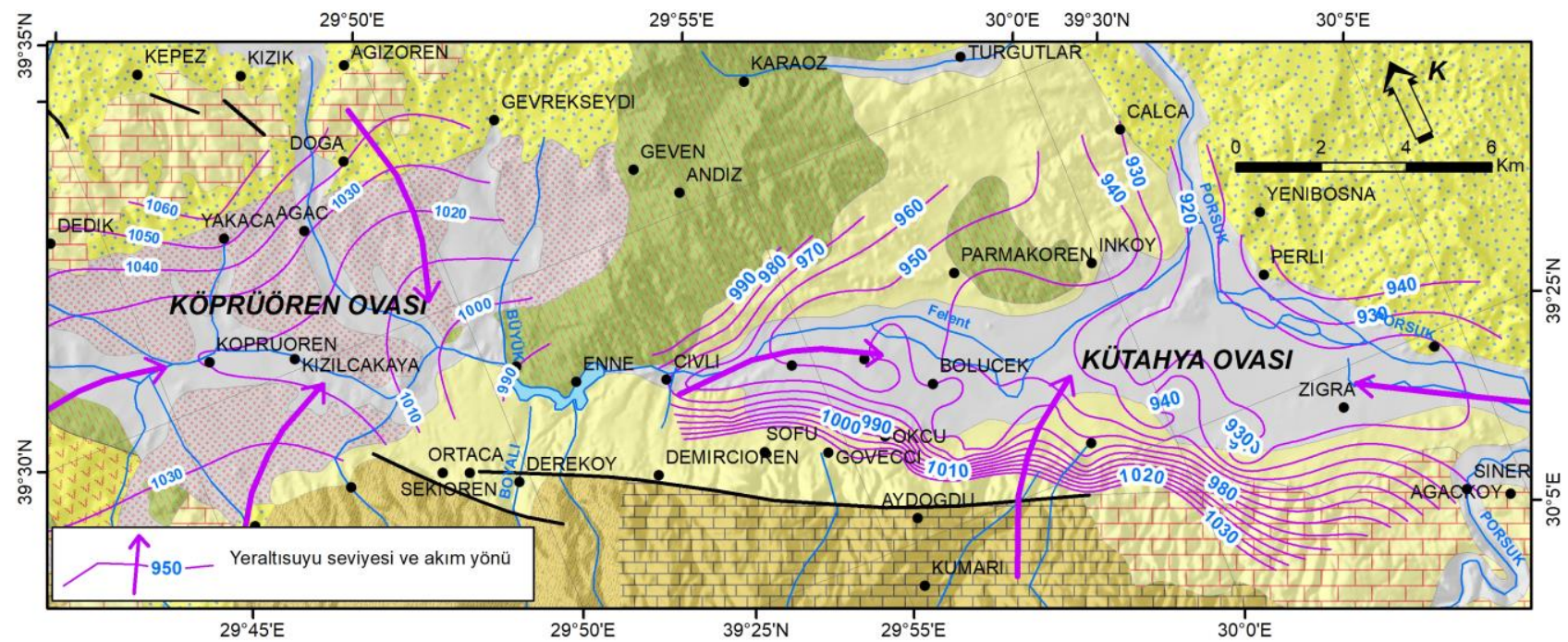

Şekil 3. Kütahya ve Köprüören ovalarında yeraltısuyu eş-seviye dağılımı 
Tablo 1. Örnekleme noktalarının UTM (ED50) koordinatları ve fiziksel ölçüm sonuçları

\begin{tabular}{|c|c|c|c|c|c|c|c|c|}
\hline Kod & Lokasyon & Tür & Doğu & Kuzey & $\begin{array}{l}\text { Kot } \\
(\mathrm{m})\end{array}$ & $\mathrm{pH}$ & $\begin{array}{c}\text { EC } \\
(\mu \mathrm{S} / \mathrm{cm})\end{array}$ & $\mathrm{T}\left({ }^{\circ} \mathrm{C}\right)$ \\
\hline L1 & Köprüören & Kuyu & 737631 & 4376805 & 1022 & 7.67 & 1689 & 9.0 \\
\hline $\mathrm{L} 2$ & Köprüören dere & Dere & 736802 & 4376630 & 1007 & 8.25 & 616 & 10.0 \\
\hline L3 & Gümüşköy & Kuyu & 737875 & 4373780 & 1041 & 8.25 & 662 & 9.1 \\
\hline $\mathrm{L} 4$ & Kızılcakaya & Kuyu & 740089 & 4373682 & 1034 & 7.79 & 668 & 10.7 \\
\hline L5 & Yakacaköy & Kuyu & 738878 & 4379080 & 1019 & 7.95 & 1141 & 11.8 \\
\hline L6 & Örenköy & Dere & 736249 & 4377723 & 1017 & 8.38 & 1096 & 9.8 \\
\hline L7 & Örenköy & Kuyu & 733663 & 4378350 & 1031 & 7.53 & 801 & 11.0 \\
\hline L8 & Ağaçköy & Kuyu & 741052 & 4378649 & 1028 & 7.71 & 798 & 12.4 \\
\hline L9 & Yoncalı & Kuyu & 744573 & 4375411 & 1002 & 7.58 & 938 & 12.0 \\
\hline L10 & Seydiköy & Kuyu & 745821 & 4378973 & 1044 & 7.75 & 740 & 12.0 \\
\hline L11 & Enne Barajı & Dere & 746339 & 4373299 & 991 & 8.7 & 615 & 11.9 \\
\hline L12 & Civli & Kuyu & 747916 & 4372536 & 965 & 7.75 & 738 & 11.4 \\
\hline L13 & Civli & Kuyu & 748195 & 4372363 & 956 & 8.4 & 323 & 7.9 \\
\hline L14 & Civli dere & Dere & 749300 & 4372206 & 946 & 7.99 & 783 & 9.5 \\
\hline L15 & Kirazpınar & Kuyu & 750552 & 4371281 & 964 & 7.46 & 802 & 10.6 \\
\hline L16 & Kirazpınar & Kuyu & 751158 & 4371832 & 946 & 7.55 & 778 & 8.8 \\
\hline L17 & Dumlupınar & Kuyu & 752078 & 4371866 & 943 & 7.78 & 829 & 12.0 \\
\hline L18 & M. Ali Ceylan & Kuyu & 750797 & 4370258 & 973 & 7.92 & 475 & 12.7 \\
\hline L19 & Evliya Çelebi & Kuyu & 753326 & 4368794 & 956 & 7.89 & 662 & 10.0 \\
\hline $\mathrm{L} 20$ & Y. Selim Külliye & Kuyu & 752820 & 4370878 & 948 & 7.78 & 668 & 13.5 \\
\hline $\mathrm{L} 21$ & M. Ali Yurttaş & Kuyu & 753751 & 4370311 & 942 & 7.42 & 1567 & 12.7 \\
\hline L22 & Parmakören & Dere & 755195 & 4370012 & 928 & 7.83 & 857 & 11.4 \\
\hline $\mathrm{L} 23$ & Parmakören & Kuyu & 754457 & 4371832 & 932 & 7.52 & 837 & 12.6 \\
\hline $\mathrm{L} 24$ & Parmakören & Kuyu & 753850 & 4372435 & 935 & 7.47 & 793 & 12.5 \\
\hline $\mathrm{L} 25$ & Parmakören & Kuyu & 752802 & 4372374 & 940 & 7.56 & 738 & 12.2 \\
\hline L26 & Parmakören & Dere & 752616 & 4372033 & 939 & 7.81 & 744 & 9.6 \\
\hline $\mathrm{L} 27$ & TOKİ dere & Dere & 756713 & 4370142 & 930 & 8.17 & 877 & 10.1 \\
\hline L28 & İnköy mera & Kuyu & 756991 & 4370374 & 929 & 7.7 & 1853 & 11.0 \\
\hline L29 & İnköy mera & Kuyu & 757529 & 4370786 & 926 & 7.85 & 742 & 12.7 \\
\hline L30 & Sanayi & Kuyu & 755883 & 4368555 & 937 & 7.44 & 832 & 13.6 \\
\hline L31 & Şeker Fab. Yanı & Kuyu & 757044 & 4368941 & 940 & 7.63 & 814 & 13.8 \\
\hline L32 & İstasyon & Kuyu & 758218 & 4367922 & 923 & 7.55 & 1486 & 7.2 \\
\hline L33 & H. Güral Anaokulu & Kuyu & 243047 & 4366536 & 916 & 7.71 & 736 & 16.0 \\
\hline L34 & Zığra & Kuyu & 245567 & 4366518 & 903 & 7.27 & 1362 & 11.8 \\
\hline L35 & Zığra2 & Kuyu & 245957 & 4366107 & 912 & 7.38 & 778 & 11.8 \\
\hline L36 & İkizhüyük & Kuyu & 247264 & 4366669 & 909 & 8.01 & 656 & 12.5 \\
\hline L37 & İkizhüyük & Kuyu & 246270 & 4368218 & 917 & 8.32 & 617 & 14.6 \\
\hline L38 & Vefa & Kuyu & 241967 & 4368218 & 962 & 7.89 & 1175 & 12.5 \\
\hline L39 & Polisevi & Kuyu & 241913 & 4368907 & 925 & 7.56 & 709 & 13.6 \\
\hline L40 & Perli dere & Dere & 242551 & 4370205 & 923 & 7.93 & 847 & 12.2 \\
\hline L41 & Perli & Kuyu & 244403 & 4369525 & 918 & 8.03 & 567 & 12.4 \\
\hline L42 & Yenibosna & Kuyu & 243880 & 4372144 & 925 & 7.52 & 1098 & 13.5 \\
\hline L43 & Porsuk & Dere & 244301 & 4372641 & 943 & 7.89 & 884 & 14.2 \\
\hline
\end{tabular}

Not: L1 ve L32 arasındaki nolu örnekler 35. Zon, diğer örnekler 36.Zon içinde yer almaktadır 
Tablo 2. Örneklenen su noktalarının majör iyon analiz sonuçları (ppm) ve hesaplanan $\mathrm{pCO}_{2}$ değerleri

\begin{tabular}{|c|c|c|c|c|c|c|c|c|c|c|}
\hline Kod & $\mathrm{Na}$ & $\mathrm{K}$ & $\mathrm{Mg}$ & $\mathrm{Ca}$ & $\mathrm{Cl}$ & $\mathrm{SO}_{4}$ & $\mathrm{HCO}_{3}$ & $\mathrm{NO}_{3}$ & $\begin{array}{c}\text { Analiz } \\
\text { hatası }(\%)\end{array}$ & $\begin{array}{l}\mathrm{pCO}_{2} \\
\text { (atm) }\end{array}$ \\
\hline L1 & 55.0 & 181 & 81.2 & 103.8 & 51.9 & 215.1 & 586.3 & 128.6 & 3.46 & -2.1 \\
\hline L2 & 13.9 & 2.2 & 50.3 & 67.1 & 10.7 & 24.1 & 402.7 & 7.13 & 3.99 & -2.8 \\
\hline L3 & 16.3 & 1.1 & 19.0 & 116.0 & 10.0 & 81.5 & 343.5 & 5.12 & 2.39 & -2.8 \\
\hline L4 & 4.2 & 1.8 & 19.0 & 117.3 & 9.1 & 44.7 & 373.1 & 10.56 & 1.11 & -2.3 \\
\hline L5 & 20.5 & 24.3 & 78.2 & 125.4 & 49.5 & 109.3 & 533.0 & 51.77 & 3.53 & -2.3 \\
\hline L6 & 22.6 & 6.8 & 110.6 & 75.2 & 11.2 & 152.7 & 579.6 & 7.24 & 3.24 & -2.8 \\
\hline L7 & 10.7 & 19.2 & 64.6 & 76.1 & 12.1 & 52.2 & 467.9 & 13.30 & 3.84 & -2.0 \\
\hline L8 & 11.7 & 3.4 & 68.9 & 76.6 & 13.5 & 156.7 & 367.2 & 25.55 & 0.06 & -2.3 \\
\hline L9 & 20.7 & 2.0 & 45.4 & 143.2 & 13.7 & 133.8 & 503.4 & 0.65 & 1.67 & -2.0 \\
\hline L10 & 12.5 & 2.1 & 58.1 & 79.7 & 8.4 & 27.5 & 481.9 & 6.80 & 2.92 & -2.2 \\
\hline L11 & 13.7 & 3.5 & 49.2 & 64.8 & 10.1 & 115.5 & 307.4 & 0.14 & 1.45 & -3.4 \\
\hline L12 & 9.1 & 0.9 & 34.6 & 115.3 & 12.4 & 41.7 & 438.3 & 1.73 & 3.38 & -2.2 \\
\hline L13 & 7.7 & 0.4 & 25.8 & 25.7 & 18.6 & 9.5 & 177.7 & 0.01 & 1.73 & -3.3 \\
\hline L14 & 10.5 & 1.9 & 45.1 & 106.7 & 13.2 & 106.3 & 414.6 & 0.29 & 0.81 & -2.5 \\
\hline L15 & 8.5 & 0.2 & 46.9 & 111.3 & 15.1 & 33.7 & 444.2 & 36.26 & 4.20 & -1.9 \\
\hline L16 & 10.0 & 0.8 & 43.1 & 90.8 & 16.6 & 30.7 & 402.7 & 32.54 & 1.77 & -2.1 \\
\hline L17 & 16.5 & 7.2 & 49.4 & 93.3 & 25.2 & 45.0 & 420.5 & 41.14 & 2.27 & -2.3 \\
\hline L18 & 3.4 & 0.9 & 31.6 & 60.6 & 2.8 & 2.6 & 325.7 & 5.72 & 2.06 & -2.5 \\
\hline L19 & 8.4 & 1.6 & 49.4 & 87.2 & 8.2 & 103.2 & 385.0 & 0.13 & 0.97 & -2.4 \\
\hline L20 & 10.6 & 1.7 & 35.1 & 89.8 & 13.1 & 27.8 & 385.0 & 15.43 & 2.42 & -2.3 \\
\hline L21 & 61.0 & 19.8 & 98.6 & 173.8 & 100.1 & 202.1 & 639.6 & 95.15 & 2.30 & -1.7 \\
\hline L22 & 22.7 & 3.0 & 53.7 & 104.9 & 28.7 & 116.9 & 425.4 & 7.94 & 1.60 & -2.3 \\
\hline L23 & 24.2 & 0.9 & 49.9 & 110.3 & 17.8 & 122.9 & 426.4 & 4.86 & 2.58 & -2.0 \\
\hline L24 & 25.7 & 1.5 & 47.5 & 105.5 & 22.6 & 97.0 & 408.6 & 23.56 & 2.89 & -2.0 \\
\hline L25 & 16.3 & 0.9 & 37.6 & 110.4 & 17.7 & 62.1 & 414.6 & 3.74 & 3.79 & -2.0 \\
\hline L26 & 19.1 & 2.4 & 43.7 & 97.5 & 18.1 & 107.2 & 366.4 & 1.69 & 3.00 & -2.4 \\
\hline L27 & 23.7 & 3.4 & 56.4 & 99.9 & 30.3 & 112.5 & 425.6 & 6.45 & 2.09 & -2.7 \\
\hline L28 & 77.7 & 6.2 & 137.7 & 194.1 & 169.0 & 606.5 & 544.9 & 2.71 & -3.58 & -2.1 \\
\hline L29 & 19.7 & 2.3 & 53.6 & 79.6 & 19.3 & 49.0 & 426.4 & 5.42 & 3.64 & -2.3 \\
\hline L30 & 20.5 & 18.7 & 38.3 & 104.8 & 19.6 & 72.7 & 414.6 & 21.96 & 2.27 & -1.9 \\
\hline L31 & 22.5 & 15.7 & 36.4 & 95.5 & 21.7 & 69.1 & 390.9 & 38.06 & 0.48 & -2.1 \\
\hline L32 & 98.1 & 17.6 & 93.1 & 138.1 & 95.7 & 198.4 & 645.5 & 27.57 & 3.78 & -1.9 \\
\hline L33 & 16.4 & 0.5 & 28.9 & 111.8 & 30.0 & 46.7 & 385.0 & 14.84 & 1.82 & -2.2 \\
\hline L34 & 53.2 & 0.9 & 27.6 & 187.8 & 137.8 & 206.3 & 302.0 & 14.50 & 2.25 & -1.9 \\
\hline L35 & 12.7 & 0.4 & 16.7 & 144.8 & 23.1 & 54.7 & 396.8 & 30.73 & 2.05 & -1.9 \\
\hline L36 & 13.0 & 15.7 & 33.7 & 81.4 & 12.1 & 41.9 & 367.2 & 14.06 & 2.13 & -2.5 \\
\hline L37 & 14.7 & 2.7 & 26.7 & 86.8 & 12.0 & 32.7 & 337.6 & 3.79 & 4.40 & -2.9 \\
\hline L38 & 55.5 & 11.1 & 64.9 & 116.3 & 51.9 & 213.3 & 426.4 & 25.43 & 1.94 & -2.4 \\
\hline L39 & 18.1 & 11.6 & 31.3 & 71.9 & 10.8 & 40.2 & 325.7 & 18.57 & 3.31 & -2.1 \\
\hline L40 & 26.2 & 5.1 & 46.0 & 95.7 & 30.9 & 103.6 & 379.0 & 23.22 & 0.79 & -2.5 \\
\hline L41 & 7.0 & 1.5 & 27.2 & 81.2 & 5.4 & 18.9 & 331.7 & 5.02 & 4.44 & -2.6 \\
\hline L42 & 28.5 & 8.7 & 74.6 & 111.5 & 39.7 & 195.9 & 361.3 & 81.73 & 2.99 & -2.1 \\
\hline L43 & 31.6 & 8.4 & 30.9 & 91.6 & 28.1 & 49.8 & 414.6 & 0.35 & 2.36 & -2.4 \\
\hline
\end{tabular}




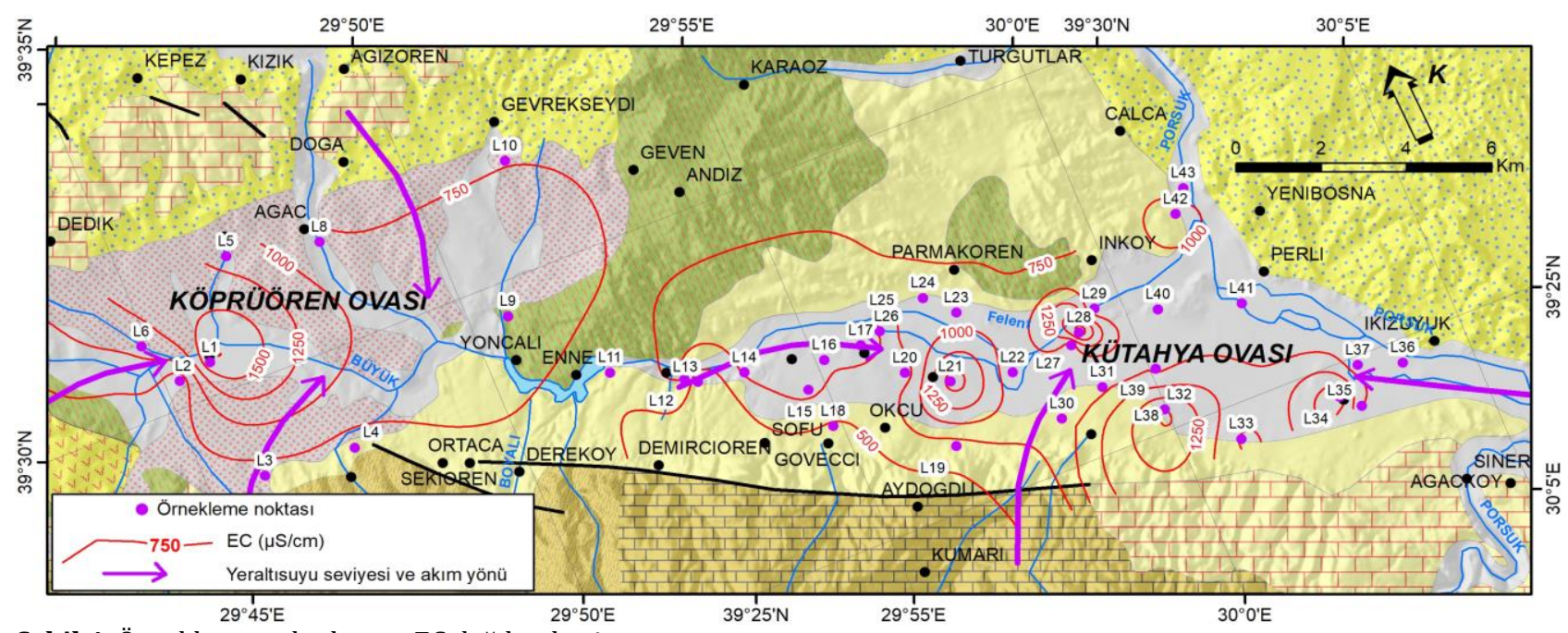

Şekil 4. Örnekleme noktaları ve EC dağılım haritası

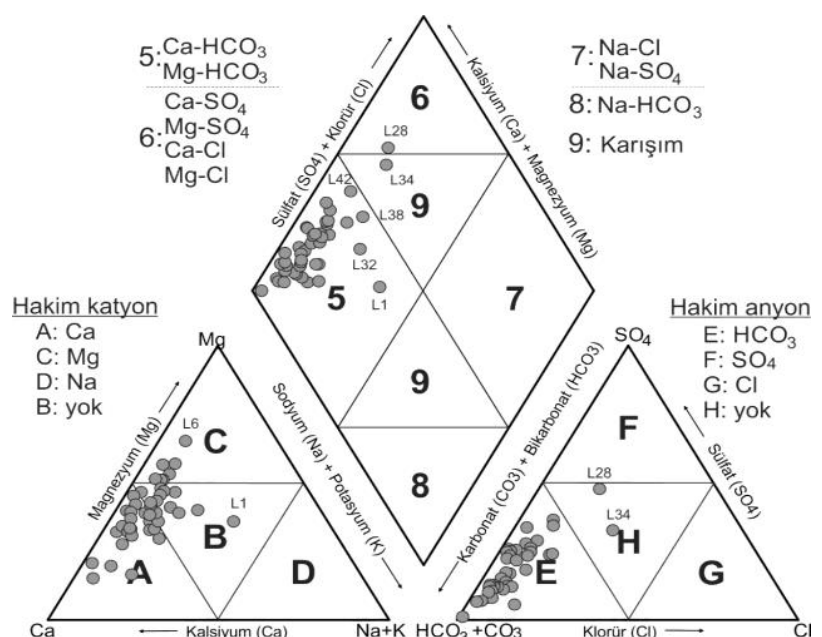

Şekil 5. Çalışma alanındaki su örneklerinin Piper diyagamı ile gösterimi

$$
\begin{gathered}
\mathrm{CaMg}\left(\mathrm{CO}_{3}\right)_{2}+2 \mathrm{H}_{2} \mathrm{O}+2 \mathrm{CO}_{2} \leftrightarrow \\
\mathrm{Ca}^{+2}+\mathrm{Mg}^{+2}+4 \mathrm{HCO}_{3}^{-}
\end{gathered}
$$

Su noktalarının Piper diyagramının katyon üçgeninde Ca ve $\mathrm{Mg}$ kenarında (A ve C bölgeleri), anyon üçgeninde de $\mathrm{HCO}_{3}$ baskın $\mathrm{E}$ bölgesinde yer almaları bu çözünme tepkimelerini destekler niteliktedir.

Kalsit ve dolomitin çözünme tepkimeleri için gerekli en önemli $\mathrm{CO}_{2}$ kaynağı atmosferik ve toprak kaynaklı $\mathrm{CO}_{2}$ dir. Çalıșma alanında örneklenen su örneklerinin kısmi $\mathrm{CO}_{2}$ basınçları $\left(\mathrm{pCO}_{2}\right)$ değerleri PhreeqC yazılımı [15] ile hesaplanmış ve Tablo 2'de sunulmuştur. Buna göre en düşük $\mathrm{pCO}_{2}$ değeri 10-3.4 atm ile Enne Baraj gölünde atmosferik $\mathrm{CO}_{2}\left(10^{-3.5}\right.$ atm) ile denge koşuluna yakın bir değerde hesaplanmıștır. Yeraltısuyu örneklerinde ise en düşük $\mathrm{pCO}_{2}$ değeri bekleneceği gibi örnekler arasında en düşük iyonik derişime sahip L13 örneğinde (Civli, EC: $313 \mu \mathrm{S} / \mathrm{cm}) 10^{-3.3}$ atm olarak hesaplanmıştır. Diğer örneklerde ise atmosferik değerden 4 ile 58 kat arasında değișen daha yüksek $\mathrm{pCO}_{2}$ değerleri hesaplanmıştır. $\mathrm{Bu}$ durumdan, çalışma alanındaki suların $\mathrm{CO}_{2}$ kaynağının toprak zonunda üretilen $\mathrm{CO}_{2}$ olduğu sonucunu çlkarmak mümkündür.
Piper diyagramındaki konumlarına göre L1, L28 ve L38 nolu örneklerin karbonatların çözünmesi dışında farklı süreçlerden de etkilenmiş oldukları anlașılmaktadır. İnceleme alanında örneklemesi yapılan su noktalarından en yüksek EC değerlerine (1363-1853 $\mu \mathrm{S} / \mathrm{cm}$ ) sahip bu örnekler $\mathrm{Na}$ ile $\mathrm{SO}_{4}$ ve $\mathrm{Cl}$ bakımından kısmen zenginleşmiştir. $\mathrm{SO}_{4}$ ve $\mathrm{Cl}$ zenginleşmesine gölsel çökeller içinde olması muhtemel jips, anhidrit ve halit gibi minerallerin çözünmesinin neden olması mümkündür.

Suların kimyasal özelliklerini denetleyen süreçleri incelemek için majör iyonlar, $\mathrm{NO}_{3}$ ve $\mathrm{EC}$ arasında Pearson korelasyon analizi gerçekleştirilmiştir. Elde edilen korelasyon matrisi ve belirlenen anlamlılık düzeyleri Tablo 3'te yer almaktadır. EC ile en yüksek korelasyon (0.92) $\mathrm{Ca}+\mathrm{Mg}$ ile sağlanmaktadır. Bu yüksek katsayı suların kimyasını denetleyen en önemli sürecin karbonatların (kalsit ve dolomit) çözünmesi ile olduğu anlaşılmaktadır. $\mathrm{HCO}_{3}$ için en yüksek korelasyon katsayının $\mathrm{Ca}+\mathrm{Mg}$ ile elde edilmiş olması bu süreci destekler niteliktedir. Bunun dışında EC ile $\mathrm{Na}$ ve $\mathrm{Cl}$ arasındaki yüksek korelasyon katsayıları (0.88 ve 0.85$)$ halitin $(\mathrm{NaCl})$ çözünmüş olduğuna işaret etmektedir. $\mathrm{Na}-\mathrm{Cl}$ arasındaki korelasyon katsayısı 0.85 olup $\mathrm{Ca}-\mathrm{SO}_{4}, \mathrm{Na}-\mathrm{SO}_{4}, \mathrm{Na}-$ $\mathrm{HCO}_{3}$ arasındaki korelasyon katsayı genelde $0.5^{\prime}$ ten küçüktür. Bu sonuçlar, $\mathrm{CaSO}_{4}, \mathrm{Na}_{2} \mathrm{SO}_{4}$ ve $\mathrm{NaHCO}_{3}$ bölgedeki sulardaki çözünürlüğünün $\mathrm{NaCl}$ kadar baskın olmadığını ifade etmektedir.

\begin{tabular}{|c|c|c|c|c|c|c|c|c|}
\hline & $\mathrm{Cl}$ & $\mathrm{NO}_{3}$ & $\mathrm{SO}_{4}$ & $\mathrm{HCO}_{3} \mathrm{Na}$ & $\mathrm{K}$ & $\mathrm{Mg}$ & $\mathrm{Ca}$ & $\mathrm{Ca}+\mathrm{Mg}$ \\
\hline $\mathrm{Cl}$ & 1 & & & & & & & \\
\hline $\mathrm{NO}_{3}$ & 0.29 & 1 & & & & & & \\
\hline $\mathrm{SO}_{4}$ & $0.82^{*}$ & 0.22 & 1 & & & & & \\
\hline $\mathrm{HCO}_{3}$ & $0.41^{*}$ & $0.44^{*}$ & $0.46^{*}$ & & & & & \\
\hline $\mathrm{Na}$ & $0.85^{*}$ & $0.37^{* *}$ & $0.76^{*}$ & $0.60 * 1$ & & & & \\
\hline $\mathrm{K}$ & 0.16 & $0.72^{*}$ & 0.22 & $0.39 * 0.34^{* *}$ & 1 & & & \\
\hline $\mathrm{Mg}$ & $0.58^{*}$ & $0.37 * *$ & $0.76^{*}$ & $0.75^{*} 0.65^{*}$ & 0.28 & 1 & & \\
\hline $\mathrm{Ca}$ & $0.78^{*}$ & 0.26 & $0.66^{*}$ & $0.48^{*} 0.63^{*}$ & 0.04 & $0.33^{* *}$ & ${ }^{k} 1$ & \\
\hline $\mathrm{Ca}+\mathrm{Mg}$ & $0.81^{*}$ & $0.39 *$ & $0.87^{*}$ & $0.77^{*} 0.78^{*}$ & 0.22 & $0.87^{*}$ & $0.76^{*}$ & \\
\hline EC & $0.85^{*}$ & $0.57 *$ & $0.83^{*}$ & $0.74^{*} 0.88^{*}$ & $0.49^{*}$ & $0.77^{*}$ & $0.74^{*}$ & * $0.92 *$ \\
\hline
\end{tabular}

Tablo 3. Kimyasal parametrelerin korelasyon matrisi 
Korelasyon matrisinin sunmuş olduğu diğer önemli bulgu $\quad \mathrm{K}^{-\mathrm{NO}_{3}}$ arasındaki görece yüksek (0.72) korelasyon katsayısıdır. Bölgenin tarım arazisi olması nedeniyle gübreleme işleminin yeraltısuyu kimyasına yer yer etki ettiği anlaşılmaktadır. Özellikle L1 örneğinde $\mathrm{K}$ iyonunun en yüksek derişime sahip katyon olması ve $\mathrm{NO}_{3}$ derişimin $128.6 \mathrm{ppm}$ ile en yüksek olarak bu noktada gözlenmesi gübre kullanımının bir sonucu olarak yorumlanmıştır.

\subsection{Suların tarımsal sulamaya uygunlukları}

Kütahya ve Köprüören ovalarında tarımsal faaliyetin yoğun olması nedeniyle, yüzey ve yeraltısuları sulama için kullanılmaktadır. Her iki ovadaki suların tarımsal sulamaya uygunlukları basit ve güvenilir olmaları nedeniyle Wilcox (Şekil 6) ve ABD Tuzluluk Laboratuvarı (Şekil 7) diyagramları ile incelenmiştir. Her iki diyagramda yatay eksende EC yer alırken düşey eksende Wilcox diyagramında \%Na değeri, ABD Tuzluluk Laboratuvarı Diyagramında ise Sodyum Adsorbsiyon Oranı (SAR) bulunmaktadır.

Şekil 6'da yer alan Wilcox diyagramına göre çalışma alanı içindeki sular tarımsal sulama için "Çok İyi ve İyi" sınıfında yer almaktadır.

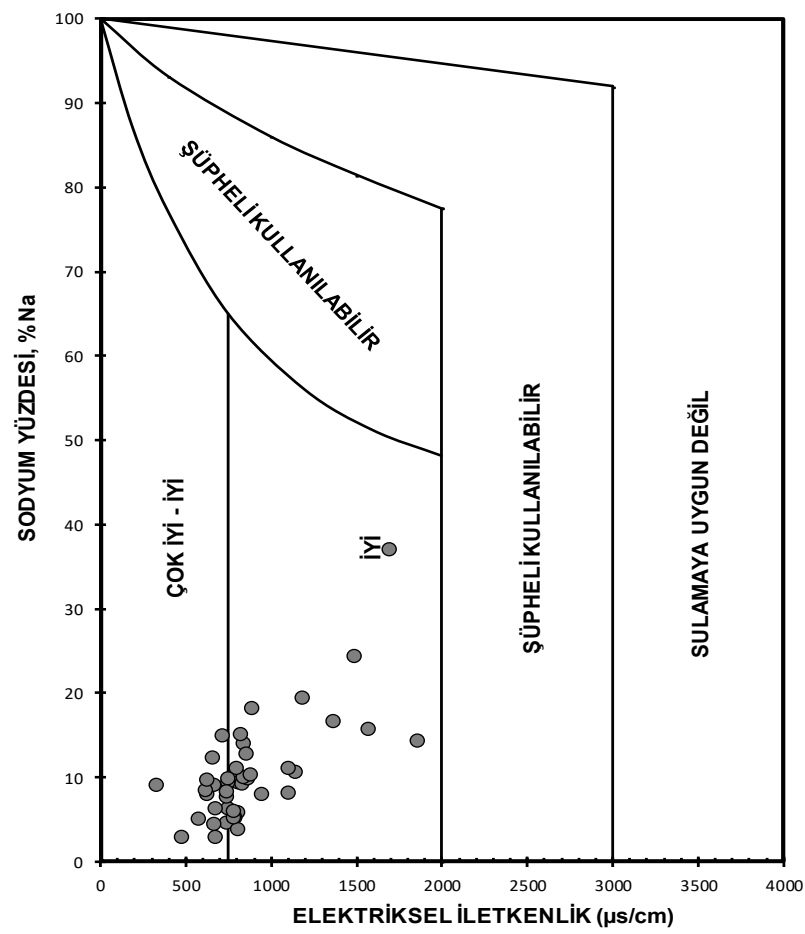

Şekil 6. Çalışma alanındaki su örneklerinin Wilcox diyagramı ile gösterimi

Şekil 7'de yer alan ABD Tuzluluk Laboratuvarı diyagraminda ise sular $\mathrm{C}_{2} \mathrm{~S}_{1}$ ile $\mathrm{C}_{3} \mathrm{~S}_{1}$ sinıflarında yer alır. $\mathrm{C}_{2} \mathrm{~S}_{1}$ sinıfı orta derecede tuzlu, az sodyumlu suları ifade edip EC değeri $750 \mu \mathrm{S} / \mathrm{cm}$ olan sular için tuzluğa orta derecede dayanıklı bütün bitkilerin sulamasında kullanılabilir. $\mathrm{C}_{3} \mathrm{~S}_{1}$ sınıfına düşen $\mathrm{EC}$ değerleri $750 \mu \mathrm{S} / \mathrm{cm}-2250 \mu \mathrm{S} / \mathrm{cm}$ olan sularda ise $\mathrm{Na}$ tehlikesi bulunmamasına karşın tuza dayanıklı bitkiler için kullanımı uygundur. Bununla birlikte ovalardaki yeraltısuyu tablasının yüzeye yakın olması sulama koşullarında etkin bir drenaj kontrolünün sağlanmasını gerektirmektedir.

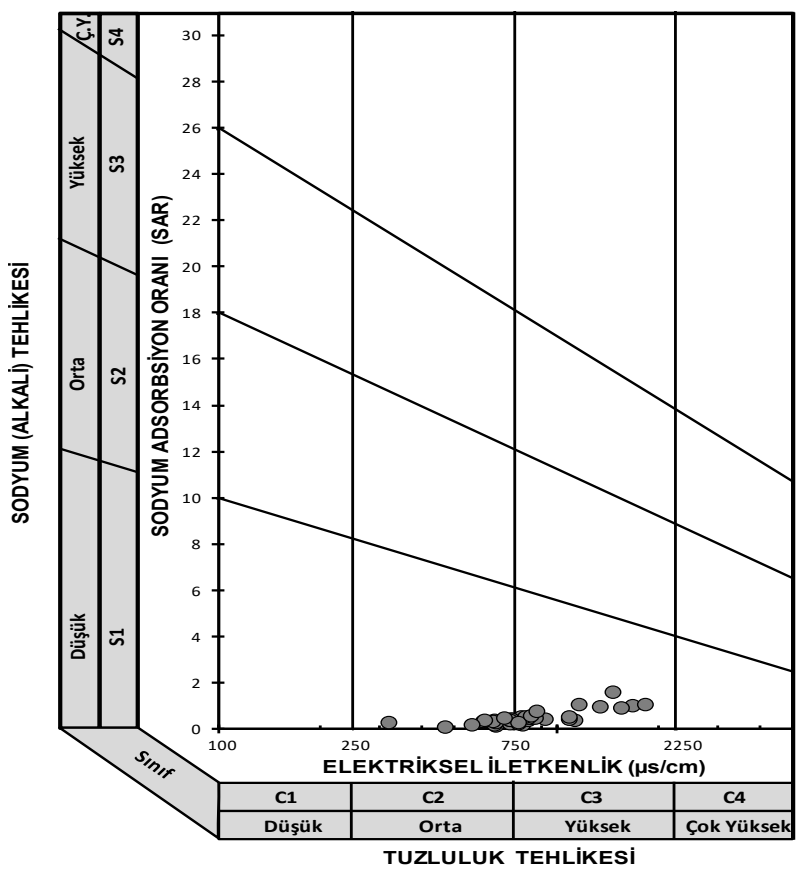

Şekil 7. Çalışma alanındaki su örneklerinin ABD Tuzluluk Laboratuvarı diyagramı ile gösterimi

\section{5. İz element analizleri}

Çalışmanın bir diğer amacını teşkil eden yüzey ve yeraltısularının iz element içeriklerinin ve kirlilik durumlarını tespit etmek için numunelerin iz element analizleri yapılmıştır. İz elementlerin analiz sonuçlarında $\mathrm{Be}, \mathrm{Al}, \mathrm{V}, \mathrm{Mn}, \mathrm{Fe}, \mathrm{Ni}, \mathrm{Zn}, \mathrm{Ga}, \mathrm{Ge}, \mathrm{As}, \mathrm{Rb}$, $\mathrm{Sr}, \mathrm{Y}, \mathrm{Zr}, \mathrm{Nb}, \mathrm{Mo}, \mathrm{Ru}, \mathrm{Rh}, \mathrm{Pd}, \mathrm{Ag}, \mathrm{Cd}, \mathrm{Sn}, \mathrm{Sb}, \mathrm{Te}, \mathrm{Cs}, \mathrm{La}$, $\mathrm{Ce}, \mathrm{Pr}, \mathrm{Sm}, \mathrm{Eu}, \mathrm{Gd}, \mathrm{Tb}, \mathrm{Ho}, \mathrm{Er}, \mathrm{Tm}, \mathrm{Yb}, \mathrm{Lu}, \mathrm{Hf}, \mathrm{Ta}, \mathrm{W}, \mathrm{Re}$, $\mathrm{Ir}, \mathrm{Au}, \mathrm{Tl}, \mathrm{Pb}, \mathrm{Th}, \mathrm{U}$ elementlerinin doğadaki izotoplarının en bol bulunanları dikkate alınmıștır. Çoğu elementin analiz sonuçları saptanma sinırının altındaki değerlerde olduğundan bu çalışmada önemli görülen belli başlı elementlerin sonuçları dikkate alınarak değerlendirme yapılmıștır. Buna göre analiz sonuçları Tablo 4'te verilmiştir.

Arsenik derişimleri L3, L4, L5, L8, L9, L10, L12, L13, L14, L15, L16, L17, L18, L19, L20, L21, L22, L23, L24, L25, L26, L27, L28, L29, L31, L32, L33, L34, L35, L38, L39, L40, L41, L42 nolu noktalarda 10 ppb'den daha düşük değerlerde olup, L1, L2, L6, L7, L11, L30, L32, L36, L37, L43 nolu noktalarda ise $10 \mathrm{ppb}$ üzeri değerlerdedir (Tablo 4). Bu noktaların dağılımına dikkat edilecek olursa, Kütahya ovasında yersel sanayinin bulunduğu kesimlerde ve Köprüören Ovasında konsantrasyon artışı gözlemlenmiştir. Köprüören ovasında yöredeki gümüș madenciliğ̈i ve maden sahası nedeniyle konsantrasyon artışı olduğu düşünülmektedir. Enne baraj gölünün bulunduğu havzada ise yüksek konsantrasyon artışı Yoncalı termal sahasının varlığı ile ilişkilendirilebilir (Şekil 8). 
Tablo 4. İz element analiz sonuçları (ppb)

\begin{tabular}{|c|c|c|c|c|c|c|c|c|c|c|c|c|c|}
\hline & $\mathrm{Al}$ & As & $\mathrm{Cr}$ & $\mathrm{Cu}$ & $\mathrm{Fe}$ & $\mathrm{Pb}$ & $\mathrm{Mn}$ & $\mathrm{Ni}$ & $\mathrm{Zn}$ & $\mathrm{Cd}$ & $\mathrm{Se}$ & $\mathrm{Ba}$ & $\mathrm{Sb}$ \\
\hline L1 & 8.987 & 71.09 & 8.007 & 0.546 & 6.422 & 1.391 & 0.22 & 0.78 & 39.01 & 0.05 & 1.52 & 124.9 & 2.607 \\
\hline L2 & 115.9 & 125.2 & 8.053 & * & 180 & 11.89 & 16.97 & 2.068 & 18.57 & 0.029 & 0.46 & 264.3 & 147.7 \\
\hline L3 & 8.586 & 3.365 & 4.305 & * & 3.345 & 1.512 & 0.265 & * & 10.57 & * & $*$ & 109.3 & 0.698 \\
\hline L4 & 11.1 & 1.299 & 5.754 & * & 6.085 & 1.071 & * & 0.116 & 7.482 & $*$ & $*$ & 47.94 & 0.543 \\
\hline L5 & 37.93 & 9.779 & 8.145 & $*$ & 118.2 & 1.339 & 28.07 & 3.338 & 53.17 & $*$ & 1.559 & 266.5 & 0.135 \\
\hline L6 & 17.28 & 14.07 & 9.314 & * & 79.03 & 1.313 & 1.597 & 12.58 & 4.556 & * & 0.247 & 141.9 & 0.76 \\
\hline L7 & 7.017 & 38.4 & 6.058 & * & 11.13 & 1.479 & * & 0.547 & 8.658 & * & 0.165 & 168.7 & 0.755 \\
\hline L8 & 7.293 & 9.505 & 5.353 & * & 2.975 & 4.768 & $*$ & $*$ & 5.51 & $*$ & 0.201 & 134.1 & 0.164 \\
\hline L9 & 8.458 & 0.133 & 5.061 & * & 12.97 & 1.011 & 63.06 & * & 58.27 & * & $*$ & 39.03 & 0.043 \\
\hline L10 & 7.997 & 4.461 & 7.423 & 11.62 & 186.2 & 2.526 & 2.69 & 0.54 & 703 & * & * & 383 & 0.08 \\
\hline L11 & 8.604 & 33.61 & 6.662 & * & 27.62 & 2.006 & 14.52 & 1.372 & 5.838 & * & * & 73.96 & 6.239 \\
\hline L12 & 9.601 & 0.071 & 6.61 & $*$ & 57.69 & 1.681 & 0.383 & $*$ & 3.783 & $*$ & $*$ & 42 & 0.13 \\
\hline L13 & 6.811 & $*$ & 2.723 & $*$ & 181.1 & 1.846 & 28.63 & $*$ & 4.538 & $*$ & $*$ & 15.75 & 0.019 \\
\hline L14 & 12.96 & 2.415 & 3.632 & $*$ & 105.9 & 1.368 & 1.054 & 0.343 & 3.51 & $*$ & 0.178 & 76.91 & 0.73 \\
\hline L15 & 7.811 & * & 5.731 & * & 8.366 & 1.49 & 1.034 & 0.24 & 173.7 & * & $*$ & 30.67 & 0.131 \\
\hline L16 & 8.832 & * & 8.344 & 7.555 & 15.67 & 1.717 & 1.098 & 4.315 & 56.42 & * & * & 32.02 & 0.019 \\
\hline L17 & 8.145 & $*$ & 4.845 & $*$ & 23.11 & 1.419 & 0.24 & $*$ & 3.364 & $*$ & 0.06 & 56.66 & 0.018 \\
\hline L18 & 5.908 & 0.259 & 5.033 & * & 3.938 & 1.649 & * & $*$ & 4.687 & $*$ & 0.044 & 34.29 & 0.074 \\
\hline L19 & 7.186 & 2.578 & 5.473 & * & 16.78 & 1.5 & 49.32 & * & 3.795 & $*$ & * & 32.72 & 0.029 \\
\hline L20 & 6.863 & 3.12 & 4.25 & * & 55.36 & 1.429 & 0.085 & * & 3.968 & * & 0.148 & 53.68 & 0.108 \\
\hline L21 & 6.081 & 0.05 & 6.817 & * & 6.204 & 1.463 & $*$ & 0.662 & 9.008 & $*$ & $*$ & 115.7 & 0.014 \\
\hline L22 & 9.42 & 4.211 & 5.814 & * & 110.8 & 1.509 & 4.156 & 1.597 & 4.555 & * & 0.135 & 67.38 & 0.607 \\
\hline L23 & 7.044 & 2.011 & 4.848 & * & 3.573 & 1.739 & 1.328 & 0.047 & 14.75 & * & $*$ & 136 & 0.329 \\
\hline L24 & 6.725 & 3.182 & 6.28 & * & 40.62 & 1.977 & 0.121 & 1.289 & 42.41 & * & 0.634 & 121.7 & 0.4 \\
\hline L25 & 6.794 & 1.372 & 3.825 & $*$ & $*$ & 1.771 & 5.849 & 0.799 & 266.8 & $*$ & $*$ & 104.5 & 0.118 \\
\hline L26 & 8.797 & 3.747 & 0.827 & * & 26.53 & 1.663 & 3.928 & 0.898 & 4.083 & * & 0.175 & 67.11 & 0.624 \\
\hline L27 & 7.178 & 5.245 & 3.844 & $*$ & 58.23 & 2.563 & 11.91 & 1.315 & 5.044 & $*$ & $*$ & 76.95 & 0.701 \\
\hline L28 & 5.989 & 2.873 & 3.808 & * & 2.315 & 1.649 & 0.899 & 2.575 & 37.35 & * & 0.594 & 73.86 & 0.405 \\
\hline L29 & 5.857 & 9.051 & 7.506 & * & 4.03 & 1.462 & 0.576 & 1.137 & 200.9 & * & * & 132.7 & 0.483 \\
\hline L30 & 5.94 & 84.06 & 2.168 & * & 18.63 & 1.263 & 16.77 & 0.399 & 307 & $*$ & $*$ & 37.4 & 5.335 \\
\hline L31 & 5.413 & 0.405 & 1.648 & $*$ & $*$ & 1.692 & 0.048 & 0.26 & 74.65 & $*$ & * & 48.74 & 0.231 \\
\hline L32 & 6.239 & 31.6 & 6.05 & 1.131 & 6.503 & 1.763 & 0.316 & 7.722 & 9.091 & $*$ & 1.922 & 47.2 & 8.876 \\
\hline L33 & 86.63 & 4.15 & 2.76 & $*$ & 164.1 & 3.657 & $*$ & $*$ & 22.84 & $*$ & $*$ & 53.15 & 0.242 \\
\hline L34 & 53.58 & 1.549 & $*$ & * & 256.8 & 3.14 & 5.554 & $*$ & 11.66 & * & 0.688 & 93.28 & 0.136 \\
\hline L35 & 23.84 & 0.847 & * & $*$ & 204.7 & 2.683 & 6.31 & $*$ & 1892 & $*$ & $*$ & 288.1 & 0.215 \\
\hline L36 & 14.2 & 14.77 & $*$ & * & 106.6 & 5.872 & $*$ & $*$ & 944 & $*$ & 0.818 & 130.9 & 0.337 \\
\hline L37 & 12.21 & 13.64 & * & * & 114.3 & 3.031 & $*$ & $*$ & 5.7 & * & $*$ & 104.9 & 0.502 \\
\hline L38 & 12.4 & 0.722 & * & * & 155.4 & 2.646 & * & * & 15.01 & * & 0.349 & 61.3 & 0.509 \\
\hline L39 & 29.89 & 0.506 & 0.391 & * & 111.3 & 2.561 & 0.672 & $*$ & 4.151 & $*$ & $*$ & 31.53 & 0.218 \\
\hline L40 & 13.06 & 5.235 & * & * & 158.2 & 3.749 & 0.636 & * & 11.24 & * & * & 51.43 & 0.549 \\
\hline L41 & 9.382 & 7.449 & $*$ & $*$ & 105.7 & 3.137 & $*$ & $*$ & 78.15 & $*$ & $*$ & 121.9 & 0.373 \\
\hline L42 & 8.589 & 6.149 & 0.874 & * & 125.1 & 3.47 & * & $*$ & 4.591 & * & 0.541 & 124.2 & 0.19 \\
\hline L43 & 20.55 & 12.33 & * & * & 131.2 & 4.35 & 14.42 & $*$ & 9.173 & * & * & 107.3 & 0.495 \\
\hline \multicolumn{14}{|c|}{ Ulusal ve uluslararası standartlara göre sınır değerler } \\
\hline TS266 & 200 & 10 & 50 & 2000 & 200 & 10 & 50 & 20 & 100 & 5 & 10 & - & 5 \\
\hline WHO & 200 & 10 & 50 & 2000 & 300 & 10 & 100 & 20 & 300 & 3 & 10 & 700 & 20 \\
\hline EPA & 200 & 10 & 100 & 1000 & 300 & 15 & 50 & - & 500 & 5 & 50 & 2000 & 6 \\
\hline
\end{tabular}




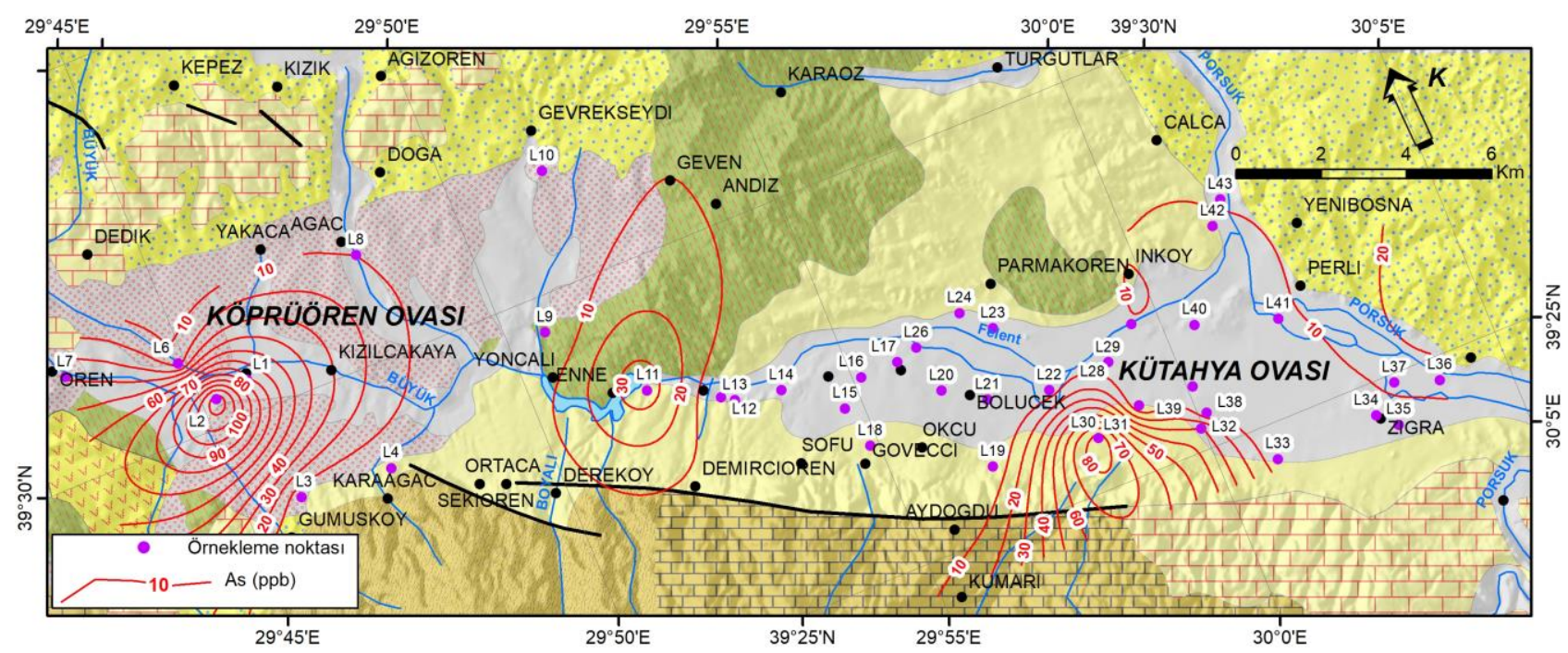

Şekil 8. As eș-derişim dağılım haritası

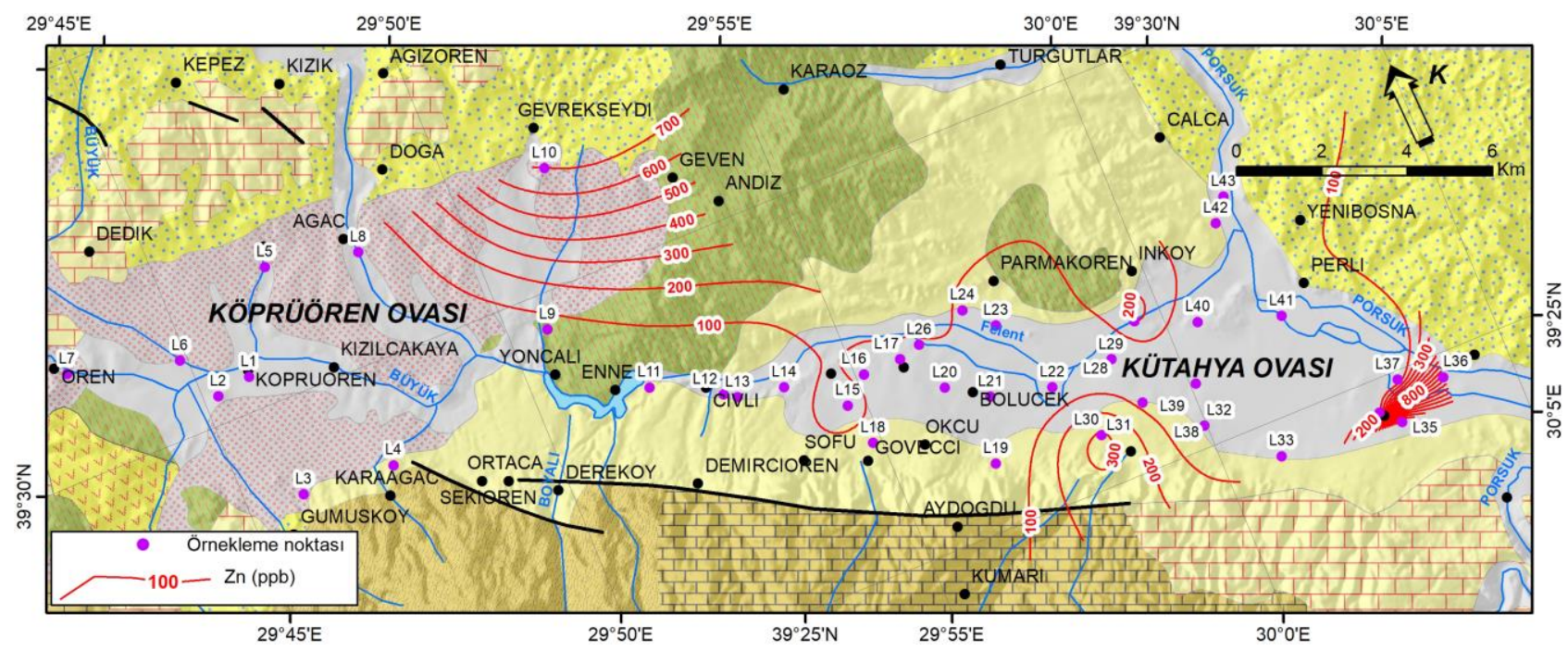

Şekil 9. Zn eş-derişim dağılım haritası

Kurşun derişimleri L2 noktası (11.69 ppb) dışında 1$6 \mathrm{ppb}$ arası değişkenlik gösterir (Tablo 4).

Çinko derişimleri Köprüören ovasındaki L10 noktasinda 703 ppb, L35 noktasında ise 1892 ppb ulaşmaktadır (Tablo 4). Her iki ovada da geniş bir aralıkta dağılım sunar (Șekil 9). Sulardaki yüksek Zn derişimlerine neden olabilecek süreç olarak L10 noktası için, bu noktaya yakın yoğun opal oluşumları ile dikkat çeken hidrotermal alterasyon ürünleri ile yeraltısularının etkileşimi düşünülmektedir. Kütahya Ovasında bulunan L35 noktasındaki yüksek Zn ile ilişkilendirilebilecek doğal bir oluşum bulunmamaktadır. Bu noktanın demiryolu hattına oldukça yakın (40-45 m) mesafede bulunması $\mathrm{Zn}$ derişimini demiryolu ile ilişkilendirmeyi mümkün kılmaktadır. $\mathrm{Bu}$ nokta ve yakınındaki L34 noktasındaki demir derişimleri diğer noktalara göre oldukça yüksek olup 200 ppb'nin üzerindedir.

Ba, 30-390 ppb arası değerlerde gözlenir. Baryum konsantrasyonu en fazla Köprüören Ovasında L2, L5, L10 ve L35 noktalarında göreceli olarak yüksek konsantrasyonlarda bulunur.

\subsection{Ulusal ve uluslararası standartlara göre suların kullanılabilirlik durumu}

Doğal suların insani tüketim amaçlı olarak kullanılabilirlikleri ulusal ve uluslararası standartlarda fiziksel, kimyasal ve biyolojik ölçütler için belirtilen sınırlar dahilinde değerlendirilir. $\mathrm{Bu}$ çalıșmada analizleri yapılan numunelerin fiziksel ve kimyasal özellikleri, ulusal (TS-266) ve uluslararası standartlara (WHO ve EPA) göre kullanılabilirlik durumu irdelenmiştir.

Sicaklık tüm noktalarda $25{ }^{\circ} \mathrm{C}^{\prime}$ den, elektriksel iletkenlik standartlarda [1,17] belirtilen $2500 \mu \mathrm{S} / \mathrm{cm}$ limit değerin altındadır. Suların pH değeri de 9.5 lik üst sinır altında olup bu fiziksel parametrelere göre tüm sular kullanıma uygundur.

Sodyum için tüm noktalar verilen limit değerin altındadır ve bu parametreye göre sular kullanıma "uygundur".

Sülfat derișimi sadece L28 noktasında standartlarda önerilen $250 \mathrm{mg} / \mathrm{L}^{\prime} l i k$ sınır değerleri aşmıştır 
Dolayısıyla L28 noktası insani tüketim amaçlı kullanılmamalıdır.

Antimon L2 noktasında 147.7 ppb derişimi ile ulusal (5 ppb, TS266) ve uluslararası standartlardaki sınır değerlerin (20 ppb, WHO; 6 ppb, EPA) oldukça üzerindedir. Diğer noktalar ise ulusal veya uluslararası standardlara uygundur.

Arsenik L1, L2, L6, L7, L11, L30, L32, L36, L37, L43 noktalarda 10 ppb'lik sınır değerin (TS266, WHO, EPA) üzerindeki derișimlerdedir. Arsenik kirliliği olan bu noktalardaki suların insani tüketim amaçlı olarak kullanılması uygun değildir.

Çinko derişiminin standartların üstünde olduğu noktalar; L10, L15, L25, L29, L30, L35 ve L36'dır. Demir sadece L34 ve L35 noktalında TS-266 standardı için izin verilen maksimum $200 \mathrm{mg} / \mathrm{L} \mathrm{limit}$ değeri aştığı görülmüştür.

Mangan sadece L9 noktasında limit değerin üzerindedir. Kurşun parametresi L2 noktası dışında diğer tüm noktalarda kullanıma "uygundur".

Kadmiyum, krom, bakır, nikel, selenyum, florür ve baryum analiz sonuçları, örneklenen tüm noktalarda standartlarda önerilen eşik değerlerinin altındadır.

\subsection{Kirlilik indisi}

Yeraltı ve yüzey sularının kirlilik (ağır metal, iyon) durumlarının incelenmesinde ölçülen parametreler ile bu parametreler için önerilen standart limitlerin karşılaştırılmasına dayalı yaklaşımlar geliştirilmiştir. Uygulama aşamasında kolay ve baskın parametrelerin belirlenmesine olanak sağlayan Kirlilik İndisi $\left(\mathrm{C}_{\mathrm{d}}\right)$ yaklaşımı [18] bu çalışma kapsamında örneklenen noktalara uygulanmıştır.

Bu yöntemde, Kirlilik İndisi $\left(C_{d}\right)$ analiz edilen her bir su örneği için ayrı ayrı hesaplanır. İndis değeri standartlarda izin verilen limit değeri aşan parametrelerin kirlilik faktörlerinin $\left(\mathrm{C}_{\mathrm{fi}}\right)$ toplamına karşılık gelir. Elde edilen değer içme suları için tehlikeli-zararlı olduğu düşünülen parametrelerin toplam etkisini özetlemektedir. Kirlilik İndisi $\left(\mathrm{C}_{\mathrm{d}}\right)$ aşağıdaki eşitlikler ile hesaplanır [18]:

$$
\begin{gathered}
C_{d}=\sum_{i=1}^{n} C_{f i} \\
C_{f i}=\frac{C_{A i}}{C_{N i}}-1
\end{gathered}
$$

Burada, $C_{f i}$, i bileşeninin kirlilik faktörü, $C_{A i}$, i bileşeninin analiz edilen derişimi, $C_{N i}$, i bileșeni için standartlarda önerilen üst derişim limitidir. Yöntemde standartlarda izin verilen derişim değerlerinin altındaki analitik değerlere sahip elementler ve iyonik türler dikkate alınmaz. Elde edilen $C_{d}$ değerine göre yeraltısuyu kirlilik durumu aşağıdaki üç kategoride gruplandırılır:

$\mathrm{Cd}<1$ (düşük), Cd = 1-3 (orta), Cd>3 (yüksek)

Kütahya ve Köprüören ovalarında örneklenen su noktalarında sadece $\mathrm{As}, \mathrm{Fe}, \mathrm{Pb}, \mathrm{Mn}, \mathrm{Zn}$ ve $\mathrm{SO}_{4}^{-2}$ parametrelerinin bazı noktalarda TS-266 standardında önerilen eșik değerleri aștığı tespit edilmiştir. Bu parametrelere göre hesaplanan $C_{f i}$ ve $C_{d}$ değerleri Tablo 5'te verilmektedir.

Uygulanan bu yönteme göre:

- $\quad$ L6, L9, L15, L34, L37 ve L43 örnekleri düşük kirlilik $\left(\mathrm{C}_{\mathrm{d}}<1\right)$

- L7, L11, L25, L29 ve L32 örnekleri orta kirlilik $\left(1<\mathrm{C}_{\mathrm{d}}<3\right)$

- $\quad$ L1, L2, L10, L30, L35 ve L36 örnekleri yüksek kirlilik $\left(\mathrm{C}_{\mathrm{d}}>3\right)$

sınıflarına girmektedir. Yüksek kirlilik sınıfına giren örneklerde ana kirletici parametreler L1 ve L2 örneklerinde As; L10, L35 ve L36 da Zn; L30 ise As ve Zn olarak belirlenmiştir.

Tablo 5. Kütahya ve Köprüören ovalarındaki su

\begin{tabular}{|c|c|c|c|c|c|c|c|c|}
\hline & \multicolumn{6}{|c|}{$C_{f i}$} & \multirow{2}{*}{$C_{d}$} & \multirow{2}{*}{$\begin{array}{l}\text { Baskın } \\
\text { Param }\end{array}$} \\
\hline & As & $\mathrm{Fe}$ & $\mathrm{Pb}$ & Mn & $\mathrm{Zn}$ & $\mathrm{SO}_{4}$ & & \\
\hline L1 & 6.11 & & & & & & 6.11 & As \\
\hline $\mathrm{L} 2$ & 11.52 & & 0.19 & & & & 11.71 & As \\
\hline L6 & 0.41 & & & & & & 0.41 & As \\
\hline L7 & 2.84 & & & & & & 2.84 & As \\
\hline L9 & & & & 0.26 & & & 0.26 & $\mathrm{Mn}$ \\
\hline \begin{tabular}{|l|}
$\mathrm{L} 10$ \\
\end{tabular} & & & & & \begin{tabular}{|l|}
6.03 \\
\end{tabular} & & 6.03 & $\mathrm{Zn}$ \\
\hline L11 & 2.36 & & & & & & 2.36 & As \\
\hline L15 & & & & & 0.74 & & 0.74 & $\mathrm{Zn}$ \\
\hline$\overline{\mathrm{L} 25}$ & & & & & 1.67 & & 1.67 & $\mathrm{Zn}$ \\
\hline L29 & & & & & 1.01 & 1.43 & 2.44 & $\mathrm{Zn}$ \\
\hline \begin{tabular}{|l} 
L30 \\
\end{tabular} & \begin{tabular}{|l|}
7.41 \\
\end{tabular} & & & & \begin{tabular}{|l|}
2.07 \\
\end{tabular} & & 9.48 & As+Zn \\
\hline L32 & 2.16 & & & & & & 2.16 & As \\
\hline L34 & & 0.28 & & & & & 0.28 & $\mathrm{Fe}$ \\
\hline L35 & & 0.02 & & & 17.92 & & 17.94 & $\mathbf{Z n}$ \\
\hline L36 & 0.48 & & & & 8.44 & & 8.92 & $\mathbf{Z n}$ \\
\hline \begin{tabular}{|l|} 
L37 \\
\end{tabular} & 0.36 & & & & & & 0.36 & As \\
\hline $\mathrm{L} 43$ & 0.23 & & & & & & 0.23 & As \\
\hline
\end{tabular}
noktalarında hesaplan $\mathrm{C}_{\mathrm{d}}$ değerleri

Kirlilik İndisi $\left(\mathrm{C}_{\mathrm{d}}\right)$ değerlerinin alansal yayılımı Şekil 10 'da gösterilmektedir. Arsenik kirliliğinin baskın olduğu L1 ve L2 örnekleri Köprüören ovasında, Eti Gümüş Tesislerinin mansabında yer almaktadır (Şekil 10). Bölgede bu işletmeye yakın, ancak daha yüksek kotlarda yer alan noktalarda (L3 ve L4) kirlilik belirtisi bulunmaması L1 ve L2 noktalarındaki arsenik kirliliğinin cevherleşmeye bağlı jeojenik veya işletmeden sızıntı kaynaklı olabileceğini düșündürmektedir. Benzer bir bulgu Köprüören Havzası'ndaki yüzey sularında rapor edilerek bu havzadaki yüzey ve yeraltı suları için en büyük kirletici kaynak maden işletmesi olduğu ifade edilmiştir [2]. 


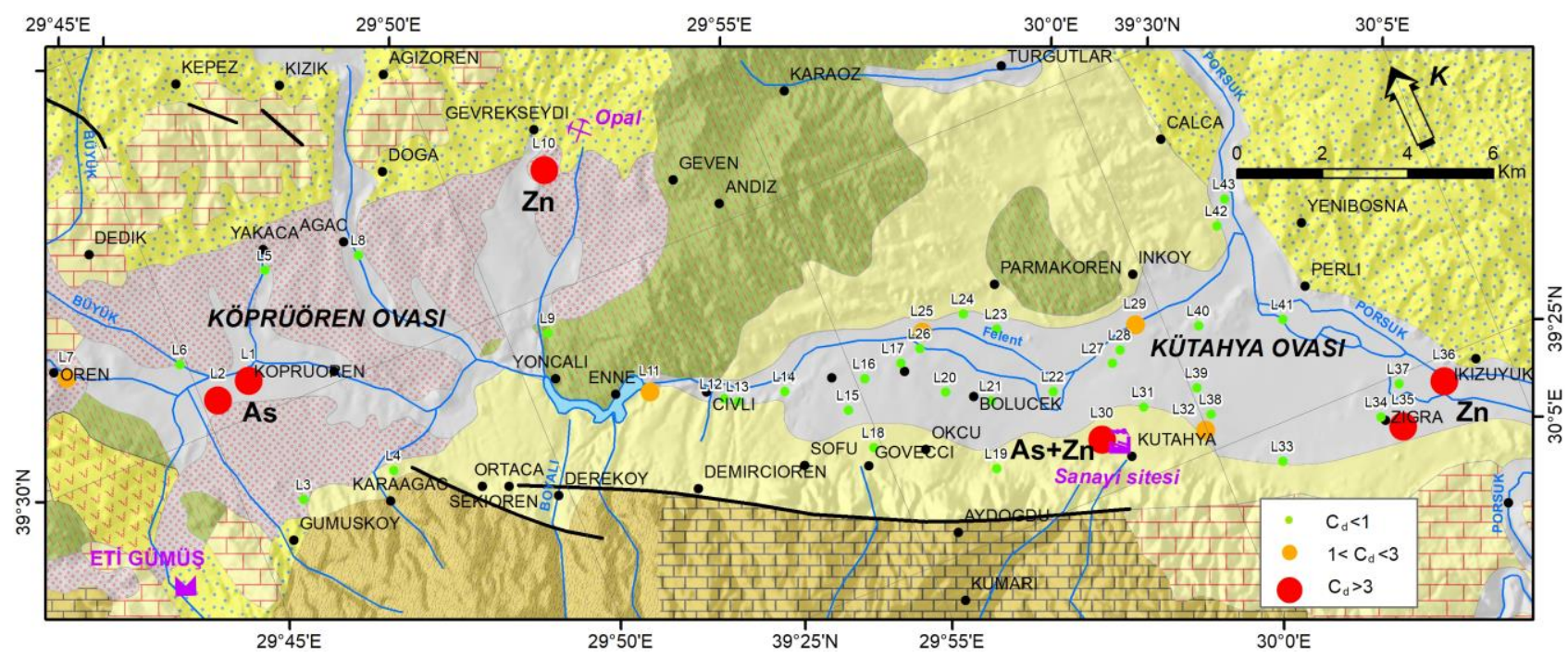

Şekil 10. Kirlilik indisi $\left(C_{d}\right)$ dağılım haritası

Zn kirliğinin baskın olduğu L10 noktası Gevrekseydi köyünde dar bir alanda hidrotermal opal oluşumlarının gözlendiği alanın akış aşağısında bulunur (Şekil 10). Bu nokta aynı zamanda Seyitömer Linyit Havzası'nın hemen yakında da bulunur. Linyit havzasına aynı uzaklıkta bulunan L8 ve L5 örneklerinde ağır metal kirliliğine rastlanılmaması nedeniyle L10 noktasındaki Zn kirliğinin jeojenik kökenli olması muhtemeldir.

As ve Zn kirliğinin birlikte bulunduğu L30 noktası Kütahya merkez sanayi bölgesinde yer alır. Bu noktadaki ağır metal kirliliğinin, sanayi atık sularının doğal sulara karışımı şeklinde açıklama mümkündür.

Zn kirliğinin var olduğu L35 ve L36 noktaları yakınında herhangi bir işletme bulunmamaktadır. $\mathrm{Bu}$ noktalardaki Zn kirliğinin demiryolu ile ilişkisi olası görülmektedir.

\section{Tartışma ve Sonuç}

Yapılan inceleme sürecinde elde edilen sonuçlar aşağıda özetlenmiştir. Kütahya ve Köprüören ovalarındaki sular kimyasal fasiyes olarak çoğunlukla $\mathrm{Ca}-\mathrm{HCO}_{3}$ ile $\mathrm{Mg}-\mathrm{HCO}_{3}$ tipi sular sınıfındadır. Suların bu fasiyes tipinde olması karbonat minerallerinin çözünmesi sonucunda gerçekleşmektedir.

Bölgedeki sular tarımsal sulama amaçlı kullanıma uygundur.

En belirgin kirletici yük olarak arsenik öne çıkmaktadır. Arsenik derişimi her iki ovada on farklı noktada 10 ppb'den daha yüksek değerlerdedir.

Noktasal olarak jeojenik veya antropojenik Zn ve Fe kirliği mevcuttur.

Kirlilik indisi parametresine göre dört farklı alanda iz elementler açısından yüksek kirlilik değerleri hesaplanmıştır. Yüksek kirlilik sınıfına giren örneklerde ana kirletici parametreler Köprüören Deresi'nde As; Gevrekseydi, Zığra ve İkizhöyük'te, Zn; Kütahya sanayi bölgesinde ise As ve $\mathrm{Zn}$ olarak belirlenmiştir.

$\mathrm{Bu}$ çalışma yağışlı dönemde gerçekleştirilmiştir. Kurak dönemlerde yüzey ve yeraltısularından gerçekleşecek buharlaşma kayıplarının suların majör iyon ve iz element derişimlerinde artışa neden olması olasıdır. Bu nedenle bölgedeki sularda kirlilik tespitine yönelik benzer bir çalışmanın kurak dönemlerde de gerçekleştirilmesine ihtiyaç duyulmaktadır.

\section{Tessekkür}

Yazarlar, değerlendirme sürecine katılarak öneri ve değerli görüşleri ile bu makaleye katkı sunan hakemlere teşekkür ederler.

\section{Kaynakça}

[1] World Health Organisation 2017. Guidelines for Drinking-Water Quality. Fourth edition incorporating the first addendum, World Health Organization, Geneva, 541s.

[2] Arslan, Ş., Çelik, M., Dokuz, U.E., Berhe, B.A. 2013. Köprüören Havzasında (Kütahya) insan kaynaklı su kirliliği. 2. Tıbbi Jeoloji Çalıștayı, 4-6 Aralık 2013, Antalya, 213-219.

[3] Arslan, Ş., Çelik, M., Dokuz, U.E., Berhe, B.A. 2014. Surface and Ground Water Quality in Köprüören Basin (Kütahya), Turkey. Proccedings of European Geosciences Union General Assembly, Vienna, Vol. 16, EGU-2014-725.

[4] Arslan, Ş., Nalbantçllar, M.T. 2012. Gümüşköy (Kütahya) dolayındaki suların risk değerlendirilmesi. 65. Türkiye Jeoloji Kurultayı, 2-6 Nisan 2012, Ankara, 126-127. 
[5] Bozkurt, Y., Arslan, R., 2017. Kamusal hizmet sunumunda suyun yeri: Kütahya Belediyesi örneği. Kastamonu Üniversitesi İktisadi ve İdari Bilimler Fakültesi Dergisi, 18(1), 201-213.

[6] Akçakaya, A., Sümer, U. M., Demircan, M., Demir, Ö., Atay, H., Eskioğlu, O., Gürkan, H., Yazıcı, B., Kocatürk, A., Şensoy, S., Bölük, E., Arabacl, H., Açar, Y., Ekici, M., Yağan, S., Çukurçayır, F. 2016. Yeni Senaryolar ile Türkiye İklim Projeksiyonları ve İklim Değişikliği-TR2015-CC. Meteoroloji İşleri Genel Müdürlüğü, Ankara, 149s.

[7] Özcan, M. 2018. Kütahya ve Köprüören Ovalarındaki Yüzey ve Yeraltısularındaki Ağır Metal Kirliliğinin İncelenmesi. Dumlupınar Üniversitesi, Fen Bilimleri Enstitüsü, Yüksek Lisans Tezi, 69s., Kütahya.

[8] MTA, 2002. Türkiye 1/500000 Ölçekli Jeoloji Haritası, İzmir paftası. MTA Genel Müdürlüğü, Ankara

[9] MTA, 2002. Türkiye 1/500000 Ölçekli Jeoloji Haritası, Ankara paftası. MTA Genel Müdürlüğü, Ankara

[10] Özburan. M. 2009. Kütahya ve çevresinin neotektonik incelemesi. Kocaeli Üniversitesi Fen Bilimleri Enstitüsü, Doktora tezi, 209s, Kocaeli.

[11] Okay. A. I. 1981. Kuzeybatı Anadolu'daki Ofiyolitlerin Jeolojisi ve Mavişist
Metamorfizması (Tavşanlı-Kütahya). Türkiye Jeoloji Kurumu Bülteni, 24, 85-95.

[12] Baş. H., 1983. Domaniç-Tavşanlı-Kütahya-Gediz Yöresinin Tersiyer Jeolojisi. Jeoloji Mühendisliği, 27, 11-18.

[13] Akdeniz, N., Konak, N., 1979. Simav-EmetTavşanlı - Dursunbey - Demirci yörelerinin jeolojisi. MTA Genel Müdürlüğü, Rapor No:6547.

[14] DSİ, 1981. Kütahya ve Köprüören ovaları hidrojeolojik etüt raporu. DSİ Genel Müdürlügü. Ankara. 65s.

[15] Parkhurst, D. L. ve Appelo C. A. J., 1999. User's quide to PHREEQC (Version 2)-a computer program for speciation, batch-reaction, onedimensional transport, and inverse geochemical calculations, USGS Water Resources Investigation Report 99-4259, 312s.

[16] Oke T. R. 1973. City size and the urban heat island. Atmospheric Environment, 7, 769-779.

[17] TS 266, 2005. Sular-İnsani Tüketim Amaçlı Sular. Türk Standardları Enstitüsü, Ankara.

[18] Backman, B., Bodiš, D., Lahermo, P., Rapant, S., Tarvainen, T., 1998. Application of a groundwater contamination index in Finland and Slovakia. Environmental Geology 36(1-2), 55-64. 